
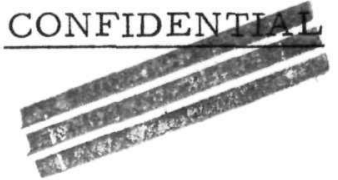

Contract No. W-7405-eng- 92

\section{UNCL.ASSIFIED}

Report No. BMI-1276

Metallurgy and Ceramics (M-3679, 21 st Ed.)

\title{
THEORETICAL STUDIES OF THE SOLIDIFICATION \\ OF URANIUM CASTINGS
}

by

Billie L. Fletcher

Ellis L. Foster, Jr.

Charles K. Franklin

Andrew Lechler

Benjamin L. Schwartz

Ronald F. Dickerson

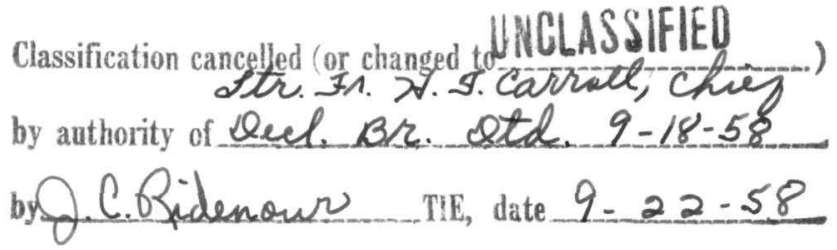

July 11,1958

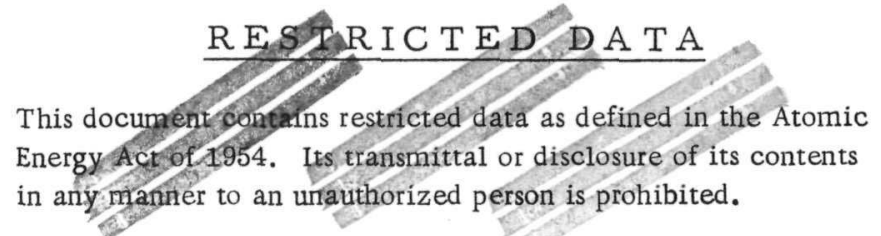

BATTELLE MEMORIAL INSTITUTE

505 King Avenue

Columbus 1, Ohio

CONFUDENIIA L

Ey

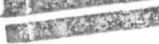




\section{DISCLAIMER}

This report was prepared as an account of work sponsored by an agency of the United States Government. Neither the United States Government nor any agency Thereof, nor any of their employees, makes any warranty, express or implied, or assumes any legal liability or responsibility for the accuracy, completeness, or usefulness of any information, apparatus, product, or process disclosed, or represents that its use would not infringe privately owned rights. Reference herein to any specific commercial product, process, or service by trade name, trademark, manufacturer, or otherwise does not necessarily constitute or imply its endorsement, recommendation, or favoring by the United States Government or any agency thereof. The views and opinions of authors expressed herein do not necessarily state or reflect those of the United States Government or any agency thereof. 


\section{DISCLAIMER}

Portions of this document may be illegible in electronic image products. Images are produced from the best available original document. 
3 and 4

TABLE OF CONTENTS

$\underline{\text { Page }}$

ABSTRACT . . . . . . . . . . . . . . . . . . . . . . . . 5

INTRODUCTION . . . . . . . . . . . . . . . . . . . . . . . . . . . . 5

DESCRIPTION OF THE SOLIDIFICATION OF A CYLINDRICAL URANIUM

CASTING . . . . . . . . . . . . . . . . . . . . . . . 8

DEVELOPMENT OF A MATHEMATICAL MODEL TO DESCRIBE TIME-

TEMPERATURE RELA TIONSHIPS IN A SOLIDIFYING CASTING . . . . . . 10

Assumptions Used in Mathematical Model. . . . . . . . . . . . . . 10

Derivation of Equations to Describe the Time-Temperature Relations in

a Solidifying Casting . . . . . . . . . . . . . . . . . . 12

Convergence and Stability of the Solution . . . . . . . . . . . . . . . 15

RESULTS . . . . . . . . . . . . . . . . . . . . . . . . . . 16

EXPERIMENTAL CONSIDERATIONS . . . . . . . . . . . . . . . . . . . 27

Physical Properties . . . . . . . . . . . . . . . . . . . . . 27

Verification of Thermal Assumptions. . . . . . . . . . . . . . . 32

Experimental Proof of the Model. . . . . . . . . . . . . . . . . . 34

Specific Experiments . . . . . . . . . . . . . . . . . . . . . . . 37

Possible Experiments to Be Conducted at NLO . . . . . . . . . . . . 38

CONCLUSIONS . . . . . . . . . . . . . . . . . . . . . . . . . 39

ACKNOWLEDGMENT . . . . . . . . . . . . . . . . . . . . . . . . . . 40

APPENDIX A

BIBLIOGRAPHY . . . . . . . . . . . . . . . . . . . . . . . A-1

APPENDIX B

COMPUTATION OF ANGLE FACTORS $\left(\mathrm{F}_{\mathrm{a}}\right)$ AND EMISSION FACTORS $\left(\mathrm{F}_{\mathrm{e}}\right)$.

APPENDIX C

TABULATION OF PHYSICAL CONSTANTS USED IN THE MATHEMATICAL MODEL . . . . . . . . . . . . . . . . . . . . . C C-1 


\title{
THEORETICAL STUDIES OF THE SOLIDIFICATION OF URANIUM CASTINGS
}

\author{
Billie L. Fletcher, Ellis L. Foster, Charles K. Franklin, \\ Andrew Lechler, Benjamin L. Schwartz, \\ and Ronald F. Dickerson
}

\begin{abstract}
The evaluation of factors involved in the production of sound uranium castings is the objective of a program of study now in progress. A mathematical model has been developed to calculate the time-temperature relationships in a cylindrical uranium casting during its solidification. Finite-difference equations are used, and the solution is obtained by use of a digital computer. Studies of the effects of such variables as the superheat, rate of pour, mold preheat, mold size, and others are possible, and their effect on casting soundness can be determined. Initial computed results demonstrate that this approach is feasible, and experiments are proposed to verify the method of analysis. The need for accurate values of the thermal properties of the casting and mold material is indicated.
\end{abstract}

\section{INTRODUCTION}

The production of sound castings of the desired design by the most economical methods is the ultimate objective of every foundryman. Since the casting of metal is one of the oldest arts of civilization, a considerable fund of knowledge has accumulated regarding empirical methods of producing sound castings. However, it is only in this century that a determined effort has been made to attack the problems of the foundryman with the full complement of scientific and mathematical tools. Recognition of the fact that the heat flow from a casting as it solidifies can be a good indication of what is occurring during the process has stimulated considerable theoretical and experimental research in this field.

Application of the theoretical approach to the study of the solidification of uranium ingots is the objective of the program of study now in progress. While it has been recognized that past efforts of a developmental nature have raised the quality of present production castings, room for improvement still exists. Further, even if the empirical significance of the conditions under which uranium ingots presently are being cast were known, the direct application of this information to uranium castings differing in shape or size would not be possible; therefore, a more basic study of the casting variables is desirable.

It is normally assumed that any liquid metal cooling in a refractory or metal mold will solidify progressively from the mold-metal interface toward the center of the casting, and solidification will proceed fastest in the direction of highest temperature gradients. Since the temperature gradients are determined by the mold-cavity shape, the method of gating and heading, the superheat, and other variables, the gradients are controllable. Achieving controlled directional solidification is a manner of stating the

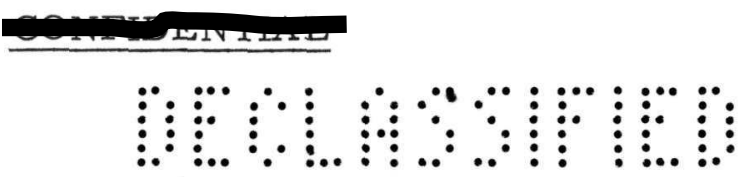


objective; i.e., if the pattern of solidification of the casting can be controlled, it is assumed that this control could be exercised in a fashion to prevent such occurrences as center-line shrink cavities.

The problem at hand is the determination of the necessary temperature gradients or the time dependency of the isothermal pattern required to obtain the desired solidification pattern.

Various techniques of obtaining the desired temperature gradients can or have been used. The se include such approaches as varying the amount of superheat, using metal chills in sand molds, adjusting the speed of pouring, placing padding sections on the casting, using various molding materials with different thermal characteristics, tapering molds, positioning gates and risers, and preheating the mold. Understandably, the applicability of these methods varies with the casting shape and molding technique. It is apparent that many variables or alternate approaches can enter into the quest for controlled directional solidification. Foundry experiments can be used to evaluate the influence of any of the se measures, but performing the necessary experiments to analyze several combinations is an expensive and time-consuming procedure; e.g., determining the effects of using three wall thicknesses combined with three different superheats would require nine melts. Also, the application of the results obtained to different materials and sizes of castings is difficult. These considerations indicate the need for other techniques.

The study of the transient temperatures in a solidifying casting has been recognized as a valuable method for understanding the mechanism and progress of solidification. (57-72, 88,92,93)* The understanding of the relationship of heat-flow patterns and the progress of solidification leads to the concept that solidification can be controlled by establishing the necessary heat flow. This concept has been the basis for many experimental and theoretical studies of casting solidification, and much of this work to 1957 has been well summarized in a monograph by $R$. W. Ruddle(78).

Four general techniques have been used in investigations of casting solidification: using thermocouples installed in the casting to examine the actual transient temperatures, pour-out techniques, electrical-analog studies, and mathematical analysis. $(39,78)$ Direct experiments are valuable and essential, but evaluating many variations is too expensive or time consuming. Pour-out techniques are generally limited to simple castings $(1,78)$, and there are many conditions where the results are misleading; e.g. , liquid that had been bridged over would solidify after the overturning of the mold. The electrical analog has been extensively used in solidification studies and has produced many interesting and useful results. (57-68) However, electrical-analog studies are limited by the number of circuit components in the equipment installation.

Mathematical analysis has been extensively used to study solidification, but the use of formal analytic methods has been of only limited success because of the severe as sumptions that must be made to obtain a solution. (39) Numerical techniques can be used in the analysis of transient heat flow (23), but in the past the scope and formulation of heat-flow problems have been restricted by the amount of manual labor required for

*Bibliography in Appendix A.

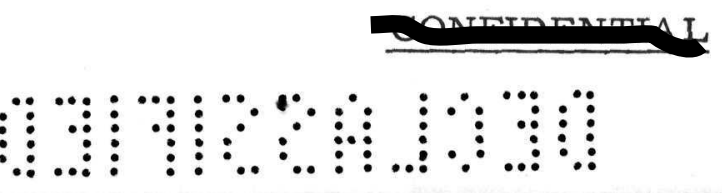


the calculations. The recent development of high-speed digital computing equipment has considerably enlarged the range of problems that can be analyzed by numerical techniques. The se considerations have led to the development of a mathematical model to be used to describe the time-temperature relationships in a solidifying casting.

The casting that is the immediate concern of the theoretical approach is a uranium ingot. This uranium ingot is a right cyclinder, 7.25 in. in diameter and about 47 in. tall. The casting is unalloyed; this simplifies the problem to some extent in that the liquidus and solidus temperatures can be considered to coincide during the solidification process. Also, the cylindrical shape permits assuming an azimuthal symmetry of the heat flow from the casting.

The research being conducted at present is organized as two successive phases. The initial phase has been the construction of a mathematical model to be used to describe the heat flow in a cylindrical uranium casting from the start of pour to completion of freezing. The second phase of the program is to be concerned with the correlation of experimental with calculated results.

Basing the mathematical model on valid assumptions as to the physical processes that occur in the casting-mold system is of primary importance, and knowledge of the physical properties of the casting and mold materials (uranium and graphite) is essential. An experimental program has been initiated to determine the pertinent physical properties of the casting and mold material.

Experimental work to be performed will check the validity of the mathematical model. Thermocouple installations in the casting and mold are to be used to obtain time-temperature relationships that can be compared with calculated results. Experimental results are to be used as a basis for verification or modification of physical assumptions, and the convergence of the calculated solution to the actual situation will be checked.

The mathematical model that has been developed may be used to study the effects of many casting variables on the progress of solidification of an unalloyed metal such as uranium. The temperature data obtained, either analytically or experimentally, are interpreted with respect to the solidification process; e.g., the detection of a portion of the casting above the solidification temperature, or still solidifying after surrounding elements have completed solidification, would be interpreted as an indication of a void forming upon complete solidification and contraction of the liquid metal. If this should occur, changes in some likely parameter, e.g., pouring time, mold preheat, superheat, etc., can be made in the mathematical model, and calculated results can be examined to see if the desired effect is produced. Correlation of such results with experimental work will be interpreted as substantiating the method of analysis. The results obtained will contribute to the knowledge of the uranium foundryman and assjst him in making decisions regarding changes in casting techniques. 


$\frac{\text { DESCRIPTION OF THE SOLIDIFICATION }}{\text { OF A CYLINDRICAL URANIUM CASTING }}$

During the pouring and solidification of a casting, a complex series of physical events takes place. The success of any mathematical analysis describing such phenomena is dependent upon as thorough an understanding of what is taking place as is possible, and for those events where exact knowledge is lacking, assumptions must be made as to what occurs. Before outlining the assumptions used in developing the mathematical model, it is important to consider a possible sequence of events from the start of pour until the completion of solidification of an unalloyed uranium ingot that is vacuum cast in a cylindrical graphite mold:

(1) The melt, at some superheat, is bottom poured into a cylindrical graphite mold which has been preheated by being in proximity with the crucible, and in some cases heat is supplied to the mold by additional induction-heating coils. Controlled preheat of the mold is sometimes used in attempts to achieve controlled directional solidification.

(2) Upon initiation of pouring, molten uranium strikes the bottom of the mold, and splattering occurs. The splattering is minimized by shaping the bottom of the mold as an inverted cone.

(3) When the liquid metal comes in contact with the mold wall, a rapid cooling of the metal occurs, depending upon the mold temperature and the effectiveness of the thermal contact. Supercooling of the liquid metal adjacent to the mold wall creates conditions suitable for the growth of equiaxed crystals.

(4) The surface of the mold in contact with the metal is rapidly heated, and the reduced rate of heat removal from the metal results in less supercooling of the liquid metal further inboard from the interface. Columnar crystals would be expected to form perpendicular to the isochrons* under the se conditions.

(5) As pouring continues, mold temperatures increase due to vertical heat flow in the mold wall. The magnitude of this flow and the mold preheat determines the rate at which the outer portions of the rising liquid metal are chilled to form the shell of the casting.

(6) Stirring of the liquid due to momentum acquired in pouring influences the initial heat transfer in the liquid metal. The continuing growth of the casting wall affects this stirring in a complex manner, tending to damp out these currents as the wall thickens. The vertical the rmal gradients in the liquid oppose formation of convection currents.

* Isochrons are defined as connected surfaces at the same temperature at the same time.

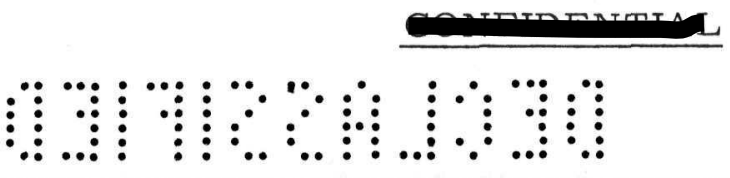


(7) Upon completion of pouring, some solidification at the interface can be expected, the amount depending upon superheat, mold preheat, and the rate of pour. Heat flow is generally perpendicular to the mold walls, and radiant heat transmission between the casting and the crucible can be found at the top of the casting. The cylindrical geometry implies an azimuthal symmetry of the heat flow.

(8) Due to the symmetry of the heat flow and the unalloyed nature of the metal, a solid front with a circular horizontal cross section moves toward the center of the casting, the velocity of this face depending upon the rate of heat removal through the mold walls.

(9) As solidification continues, a "cup" of solid casting material forms. When the wall is thick enough to support the liquid, a separation at the mold-casting interface occurs. As this separation progresses, the mode of heat transfer changes from conductive to radiative. Surface conditions of the mold and casting may be such that good thermal contact never exists.

(10) The reduced rate of heat transfer from casting to mold after this occurrence causes a reduction of the high initial inner-mold-wall temperatures, and a lower thermal gradient through the mold wall is established.

(11) The reduced heat transfer from the casting wall also allows some leveling of the thermal gradients through the casting; in fact, with a high enough superheat, it would be possible for the casting wall to remelt.

(12) Depending upon the many variables present, the rate of wall growth from various points of the casting wall differs. One possible case would be having a rate greater at the center (in a horizontal plane) than at a lower position, and the center portion might bridge over the lower liquid. But if the rate of heat removal through the bottom were sufficient, the solid front advancing from the bottom might prevent this. This possibility indicates the importance of considering the end effects when trying to achieve controlled directional solidification.

(13) As the liquid cools and solidifies, continual contraction of the metal occurs, and bridged-over volumes would be expected to be the sites of shrink cavities, the se probably being along the center line - the final part to solidify. If the top has not solidified prior to lower regions, it acts as a "feeder" for lower positions along the center line, and the result is the formation of a conical-shaped depression, since the outer top portion can be expected to have solidified soon after contact with the mold wall. 


\section{DEVELOPMENT OF A MATHEMATICAL MODEL TO DESCRIBE TIME-TEMPERATURE RELATIONSHIPS IN A SOLIDIFYING CASTING}

\section{Assumptions Used in Mathematical Model}

On the basis of the description of ingot solidification, a number of assumptions have been made which are used as a basis for developing the mathematical model. These assumptions are tentative, and modifications may be dictated by future experimental results. They are as follows:

(1) The heat flow from the casting is azimuthally symmetric, hence the solidification of the entire casting can be studied as a two-dimensional transient-heat-flow problem, the second dimension being required for consideration of end effects. Since this is a transient problem, it is necessary to consider the thermal capacity of those portions of the casting and mold being studied, and this implies using a pie slice from the center of the casting to the outer mold wall. If the casting were to lean in the mold after the wall has solidified, the symmetry conditions would not prevail, but it has been noted that cross-sectional photographs of ingots show fissures along the center line; this is considered to be evidence to support the symmetry as sumption.

(2) The cast metal is unalloyed so no distinct "liquidus" and "solidus" faces are present, the solidification being assumed to proceed as a front parallel to the isochrons.

(3) During the pouring of the ingot, the temperature of the mold wall is assumed to remain constant at assigned initial values at points above the current liquid level; this implies a disregard for part of the vertical heat flow in the mold during pouring. If experiments indicate the actual case is much different, methods of calculation can be altered to allow for vertical heat flow in the mold during pouring.

(4) A mold wash is sometimes used, and this would affect the heat flow from the casting to the mold. The influence of this wash on the emissivity and thermal conductivity of the mold wall can be included in the mathematical model.

(5) The effects of splattering of the liquid while pouring is a difficult matter to represent analytically due to its random nature, and the present attitude is that this occurrence has a negligible effect on the over-all solidification pattern.

(6) Although supercooling at the surface of the ingot may occur, the depth of this phenomenon, as evidenced by equiaxial crystal structure, is believed to be slight in respect to the over-all casting size; therefore,

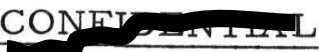

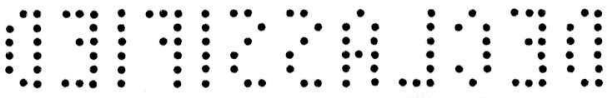


supercooling is ignored. However, it will be seen in the "Results" section that a virtual supercooling of the wall of the casting is produced by the method of solution.

(7) The sidewalls of the casting are assumed to remain in the rmal contact with the mold until a fixed depth of the casting has solidified; at this time, instantaneous separation occurs, and the heat transfer then continues as a radiative process. It is possible to vary the depth of solidification assumed to exist before separation takes place. Since the casting is done in an evacuated container, heat transfer by convection in the gap is not considered. In actuality, during the separation of the ingot and mold, there would probably be a gradual change from conduction to radiation due to surface roughness on both sides. Another complication is introduced by the variation of the interface thermal conductivity with the applied pressure $(23,87,94)$, this being in part determined by the thickness of wall solidified and the liquid pressure at that level. The bottom of the casting is regarded as remaining in contact with the mold during solidification; "hanging" of the ingot due to tapered sides or other causes would require modification of this as sumption.

(8) There may be some anisotropy of heat flow in the solid casting or mold material caused by variations of crystalline structure. These effects are presently considered as having little influence on the over-all solidification pattern, but if experimental evidence indicates otherwise, this view can be revised. The present mathematical model permits the use of thermal conductivities that differ in the vertical and horizontal directions.

(9) Dimensional changes of the casting and mold while cooling are not considered. Such calculations based on coefficients of expansion might give some indications as to the time of gap formation, but other effects such as the bulging of the solid shell of variable thickness caused by liquid pressures and structural weight make the significance of such calculations doubtful.

(10) The thermal conductivity of the solid and liquid metal and of the mold are considered as differing functions of temperature. Although the heat capacities are regarded as fixed for the range of temperatures of interest, provision can be made for their variation with temperature if this is found desirable on the basis of physical measurements.

(11) The emissivities of various surface types (uranium, graphite, coated graphite) are allowed for, and they are regarded as constant in the range of temperatures considered. 
(12) The top of the ingot is considered to be a flat surface during the period of solidification. The possibility of a cone-shaped depression forming is ignored for two reasons: since the inclination of the surface changes, the value of the "angle factor" used to determine the radiant heat transfer between the casting top and the crucible varies with time in a complex manner; also, the depression forms at a late stage of solidification since the solidification and feeding along the center line occur last, so the effects of this omission during the major part of the analysis would be negligible; bridging in lower portions of the casting, if present, would occur before the final feeding along the center line. The irregular roughness of the top also influences the angle and emission factors.

(13) During the period of solidification, environmental temperatures, used as boundary conditions for the analyses, are held constant. The environment is considered to be the inside wall of the outer cooling jacket, the bottom of the crucible, and the top of the mold adjacent to the crucible. If the variation of the se temperatures is considerable during the solidification period, the calculations can be modified to allow for this.

(14) Convective heat transfer between the casting and mold and the mold and cooling jacket is ignored since a vacuum-casting process is used.

(15) Convection within the liquid metal is ignored; the thermal gradients present in a bottom-poured cylindrical casting (cooler at the bottom) would tend to damp out convective currents, but the momentum of the liquid stream would be expected to produce some stirring. Additional complexities a re introduced by a thickening skin that would interfere with circulation of the liquid metal. On this basis, a portion of the casting that has just been poured is considered to be at the initial superheat, but this viewpoint can be modified if experiments indicate that the temperature of the liquid alters appreciably during pouring.

\section{Derivation of Equations to Describe the Time-Temperature Relations in a Solidifying Casting}

On the basis of the assumptions mentioned, the analysis of the transient heat flow in the aforementioned pie slice of the casting and mold wall is now considered. Figure 1 indicates a division of a segment of the pie slice into three cells, two in the casting and one in the mold wall, this subdivision being adequate to develop the basic equations of heat flow (the number of cells in such a segment is doubled for the actual model). In this case the upper and lower surfaces are insulated, a restriction that is removed in the fully developed mathematical model by including terms in the following equations that also account for the vertical heat flow. An increase in the number of cells improves the accuracy of the analysis since each cell temperature is considered

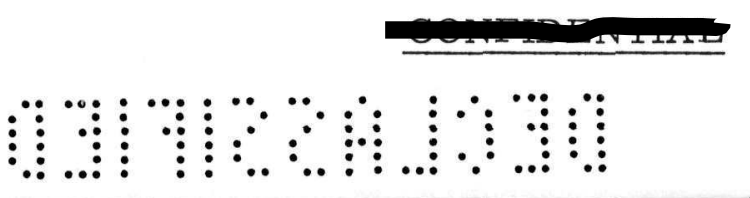


to be represented by a "central" temperature, these being $\mathrm{T}_{1}, \mathrm{~T}_{2}$, and $\mathrm{T}_{3}$ in Figure 1 $\left(\mathrm{T}_{4}\right.$ is an environmental temperature).

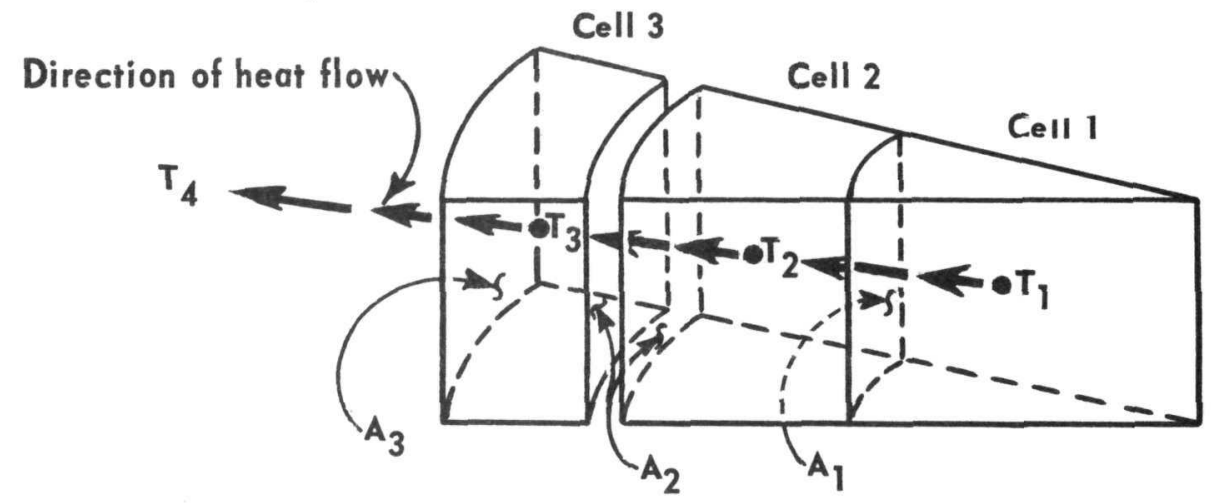

FIGURE 1. HEAT FLOW THROUGH A PIE-SHAPED SLAB

Approximating a physical system in this manner is not a new concept; the "lumped constants" used in electrical engineering are of the same nature in that the electrical behavior of continuous systems such as transmission lines is approximated by assuming that a discrete number of resistors, capacitors, and inductors make up the system. The investigations of Paschkis $(57-68)$ have been based on an analogous procedure in that the thermal system is approximated by a corresponding discrete electrical network whose electrical behavior is observed. In a sense the same thing is being done here except that computational labor is substituted for the construction and operation of the electrical analog.

On the basis of the Fourier and Stefan-Boltzmann laws, and by introducing the heat capacity of each cell (since this is a transient problem), the change of temperature of each cell during a finite time interval can be determined $(23,47,49,87)$ from the following equations:

$$
\begin{aligned}
& \Delta \mathrm{T}_{1}=\Delta \theta / \mathrm{C}_{1}\left[\mathrm{~K}_{12}\left(\mathrm{~T}_{2}-\mathrm{T}_{1}\right)\right], \\
& \Delta \mathrm{T}_{2}=\Delta \theta / \mathrm{C}_{2}\left[\mathrm{~K}_{12}\left(\mathrm{~T}_{1}-\mathrm{T}_{2}\right)+\mathrm{A}_{2} \sigma \mathrm{F}_{\mathrm{a}, 2} \mathrm{~F}_{\mathrm{e}, 2}\left(\mathrm{~T}_{3, \mathrm{k}^{-}}^{4} \mathrm{~T}_{2, \mathrm{k}}^{4}\right),\right. \\
& \Delta \mathrm{T}_{3}=\Delta \theta / \mathrm{C}_{3}\left[\mathrm{~A}_{2} \sigma \mathrm{F}_{\mathrm{a}, 2} \mathrm{~F}_{\mathrm{e}, 2}\left(\mathrm{~T}_{2, \mathrm{k}}^{4}-\mathrm{T}_{3, \mathrm{k}}^{4}\right)+\mathrm{A}_{3} \sigma \mathrm{F}_{\mathrm{a}, 3} \mathrm{~F}_{\mathrm{e}, 3}\left(\mathrm{~T}_{4, \mathrm{k}}^{4}-\mathrm{T}_{3, \mathrm{k}}^{4}\right)\right] .
\end{aligned}
$$

The following definitions of terms* apply:

$$
\begin{aligned}
T_{n} & =\text { temperature of Cell } \mathrm{n}, \mathrm{C} \\
\mathrm{T}_{\mathrm{n}, \mathrm{k}} & =\text { temperature of Cell } \mathrm{n}, \mathrm{K} \\
\Delta \mathrm{T}_{\mathrm{n}} & =\text { change of temperature of Cell } \mathrm{n} \text { in the finite time interval } \Delta \theta, \mathrm{C}
\end{aligned}
$$

- The thermal properties presently being used are listed in Appendix C.

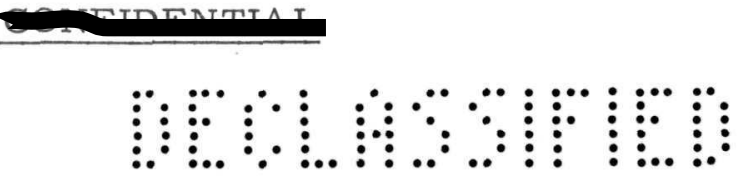




$$
\begin{aligned}
& \Delta \theta=\text { finite time interval, sec } \\
& \mathrm{C}_{\mathrm{n}}=\text { heat capacity of Cell } \mathrm{n}, \mathrm{cal} \text { per } \mathrm{C} \\
& \begin{aligned}
K_{n, n}+1= & \text { thermal conductance between cells } n \text { and } n+1\left(=k A_{n} / x_{n}\right), \\
& \operatorname{cal} /(\sec )(C)
\end{aligned} \\
& \mathrm{k}=\text { thermal conductivity of material in which cells are located, } \\
& \mathrm{cal} /(\mathrm{sec})(\mathrm{cm})(\mathrm{C}) \\
& \mathrm{x}_{\mathrm{n}}=\text { distance between centers of cells, } \mathrm{cm} \\
& A_{n}=\text { area of interface between cells, } \mathrm{cm}^{2} \\
& \mathrm{~F}_{\mathrm{a}, \mathrm{n}}=\text { angle factor* (dimensionless) } \\
& \mathrm{F}_{\mathrm{e}, \mathrm{n}}=\text { emissivity factor* (dimensionless) } \\
& \sigma=\operatorname{Stefan-Boltzmann} \text { constant }\left[1.377 \times 10^{-12} \mathrm{cal} /(\mathrm{sec})\left(\mathrm{cm}^{2}\right)\left(\mathrm{K}^{4}\right)\right] .
\end{aligned}
$$

These equations apply if heat transfer is by conduction from Cell 1 to 2 , radiation from Cell 2 to 3 , and radiation from Cell 3 to the outer cooling jacket at temperature $\mathrm{T}_{4}$. If the casting and mold walls are in thermal contact, a conductive term is used to describe the heat flow from Cell 2 to 3 . The assumption is made that the temperature gradients do not change during the time interval, and this approximation is improved as $\Delta \theta$ is made smaller. Also, since the assumption is made that $\mathrm{K}=\mathrm{kA} / \mathrm{x}$, a linear thermal gradient is implied to exist between two cells with mutual conductive heat flow; this being more valid for an increased number of cells in the same volume. Using a temperature point at the face of a.cell where radiation occurs gives a better value for the radiative heat exchange, and this is done for the casting wall in the complete model. One difference of the present method of analysis as compared with previous numerical studies is that network spacings are not dictated by consideration of the ease of manual computations. This is possible because of the availability of high-speed digital computer equipment. Use of this computational aid also makes it possible to include variable thermal conductances and capacities with little difficulty, and the fourth powers of temperature can be used for radiation calculations instead of approximating this type of heat flow with first-power differences as is commonly done in manual computations. (23)

In the mathematical model presently being used, 75 cells are employed, a typical segment being approximated by four casting and two mold wall cells. The equation for each cell is similar to Equations (1) through (3), with a term describing the radiative or conductive heat flow from each face. Alterations in the methods of computing each cell temperature are made on the following basis:

(1) Cells reaching the freezing temperature are held at that value until the heat of fusion has been released; for example, by computing

$$
-\Delta \theta / \mathrm{C}_{1}\left[\mathrm{~K}_{12}\left(\mathrm{~T}_{2}-\mathrm{T}_{1}\right)\right]
$$

\footnotetext{
- See Appendix B for computation of $\mathrm{F}_{\mathrm{a}}$ and $\mathrm{Fe}$.
} 
the total heat flow from Cell 1 in the time interval $\Delta \theta$ is determined. For each $\Delta \theta$ this value is computed while $\mathrm{T}_{1}^{\prime}=\mathrm{T}_{1}=$ freezing temperature, and account is kept of the sum of these heat losses. When the total heat loss equals the total heat of fusion of the cell, the value of $\mathrm{T}_{1}{ }^{\prime}$ is allowed to vary according to the solid thermal properties.

(2) The pouring time is allowed for by holding a particular cell at the initial superheat until the elapsed time is such that the liquid level reaches that of the cell; use of this device requires knowledge of the filling rate of the mold.

(3) The alteration from conductive to radiative heat transfer after the casting wall solidifies is accomplished by removing the appropriate conductive term from the equation and substituting a radiative term.

The decisions to release the heat of fusion, to substitute the solid for the liquid thermal properties, to delay the heat flow until the pouring of a cell is completed, and to alter the heat transfer from conductive to radiative after separation at the interface are all made automatically by the digital computer on the basis of the criteria specified.

The program for calculation of heat flow from the cylindrical casting can be readily adapted to consider alterations of dimensions of the casting and mold if a cylindrical geometry is retained. Adapting the existing program to, say, a smaller experimental-size ingot is accomplished by recalculating the dimensional and heatcapacity constants.

\section{Convergence and Stability of the Solution}

When the numerical solution of a partial differential equation is attempted, consideration must be given to the convergence and stability of the solution. Convergence is determined by the truncation error arising from the use of a finite subdivision to characterize a continuous body; the greater the number of subdivisions (cells in this case) the more nearly will the numerical results approach the corresponding exact values; failure to converge indicates the numerical method employed is unsatisfactory. The stability criterion is concerned with the growth of errors as the calculation proceeds due to the finite time increments employed and the number of significant figures that can be carried in the calculation. (49) In the present complex problem, the use of analytic methods to determine if the solution is convergent is difficult, and the best criterion for selecting an adequate number of cells is on the basis of the experience gained with the problem. (87) The results obtained with the 75 -cell model could be compared with those obtained for, say, a 300-cell model, and if the results obtained with the two models were within allowable error limits, the smaller model would be as sumed to be adequate. A more critical test, however, is whether the calculated results agree with experimental results, and this method is to be applied in testing the 75 -cell model. 
Regarding stability of the solution, one test for determining the maximum allowable time interval $(\Delta \theta)$ is available, this being based on a physical argument $(23)$; namely, the hotter a body is at one instant should not imply it will be colder at the end of the time interval for which the change in temperature is computed, i.e., the temperature of a body would not be expected to have a negative effect on its future value. By examining Equation( 1 ), it is seen that this implies

$$
\Delta \theta \leq \mathrm{C}_{1} / \mathrm{K}_{12}
$$

and similar expressions can be derived for each of the other cells. In trial computations it has been demonstrated that allowing $\Delta \theta$ to exceed this limit does result in large, unrealistic oscillations of the calculated temperature. Satisfying this criterion and at the same time using a $\Delta \theta$ that is not too small is of practical importance in that it determines the efficiency with which the calculation can be performed; picking too small a time interval requires excessive computational time to cover the period of solidification, and an excessively large $\Delta \theta$ gives the aforementioned result.

\section{RESULTS}

Preliminary calculations have been made to determine the time-temperature relationships in the production-size uranium casting while solidifying. The casting is a cylinder with a cone-shaped bottom, has a diameter of 7.25 in., a length-diameter ratio of 6.5 , and it weighs about $1200 \mathrm{lb}$.

Calculations were first made on the basis of a 20-cell division of a pie slice of the casting and mold material. Such factors as variable the rmal properties and the separation of the casting and mold were ignored, the objective being to examine the feasibility of the method of solution for a simple case. The results obtained indicated possibilities in the method of analysis, and on this basis the more complex 75 -cell model of the same casting was developed.

Some results obtained for the 20-cell model are shown in Figures 2 and 3. The time-temperature relationships of four cells are plotted; Cell 14 is next to the mold wall near the bottom of the casting, Cell 10 is adjacent to the center line at the bottom of the casting, Cell 3 is near the top next to the center line, and Cell 1 is at the top adjacent to the center line. The results plotted in the two graphs are for identical casting conditions except that the pouring time was doubled to $90 \mathrm{sec}$ for the case in Figure 3. The rapid cooling of the outer wall of the casting is apparent (Cell 14) as is the delayed cooling of the cells further inboard. Note that the initial cooling of Cell 14 is delayed from that of Cell 10 because it is above the level of Cell 10 and is the refore poured at a later time.

In both cases it was found that "bridging" had occurred, i.e., cells along the center line were found to be incompletely solidified after the outer wall and top and bottom cells had completed solidification. But in the case where the pouring time was greatest, the amount of liquid metal entrapped was decreased. This appears logical, 


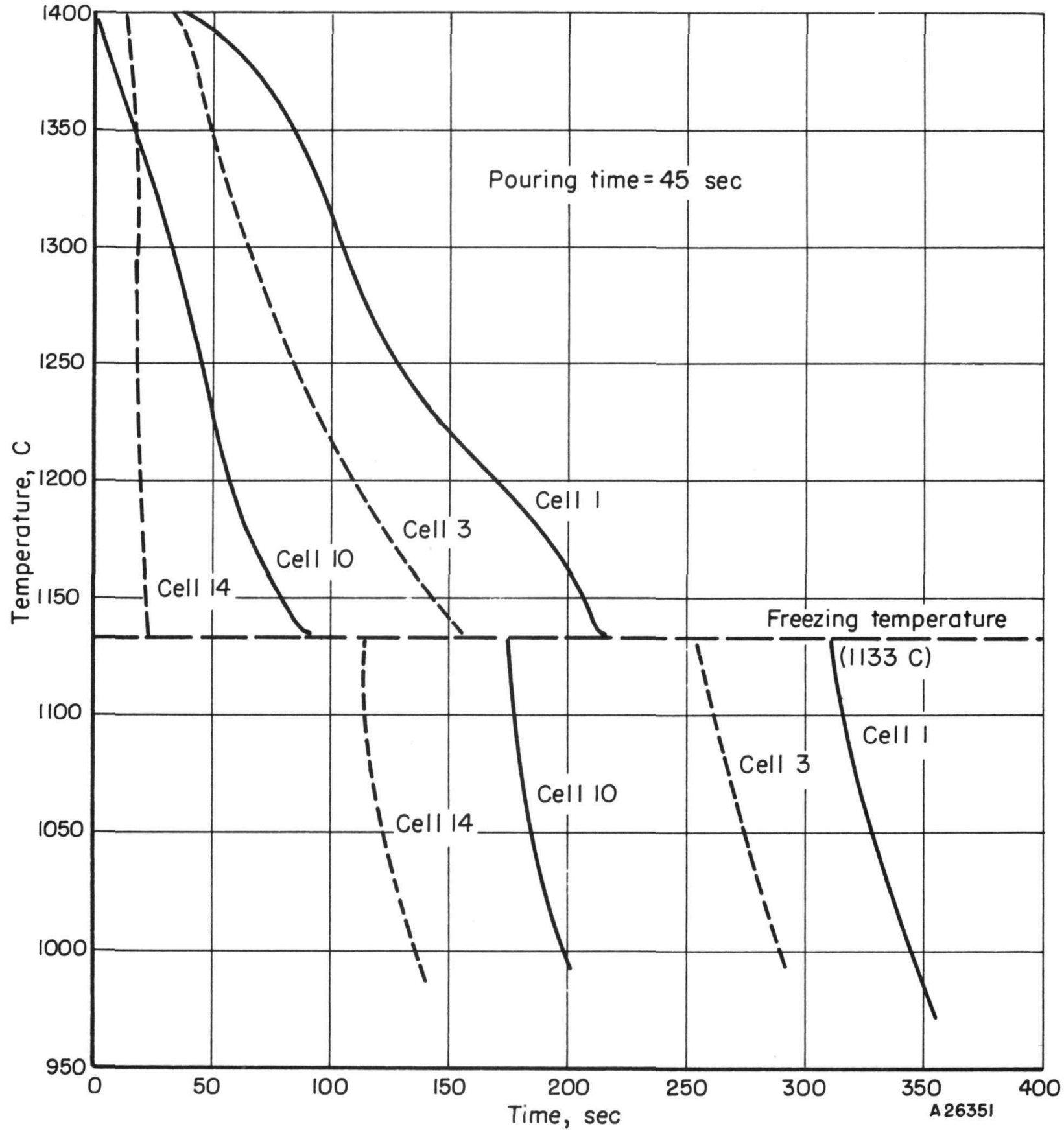

FIGURE 2. CALCULATED TEMPERATURE VERSUS TIME RELATIONSHIPS FOR 4 CELLS IN A CASTING COOLING FROM 1400 C, WITH THE HEAT OF FUSION BEING RELEASED AND THE COOLING OF UPPER CELLS DELAYED DUE TO A FINITE POURING TIME (45 SEC) 


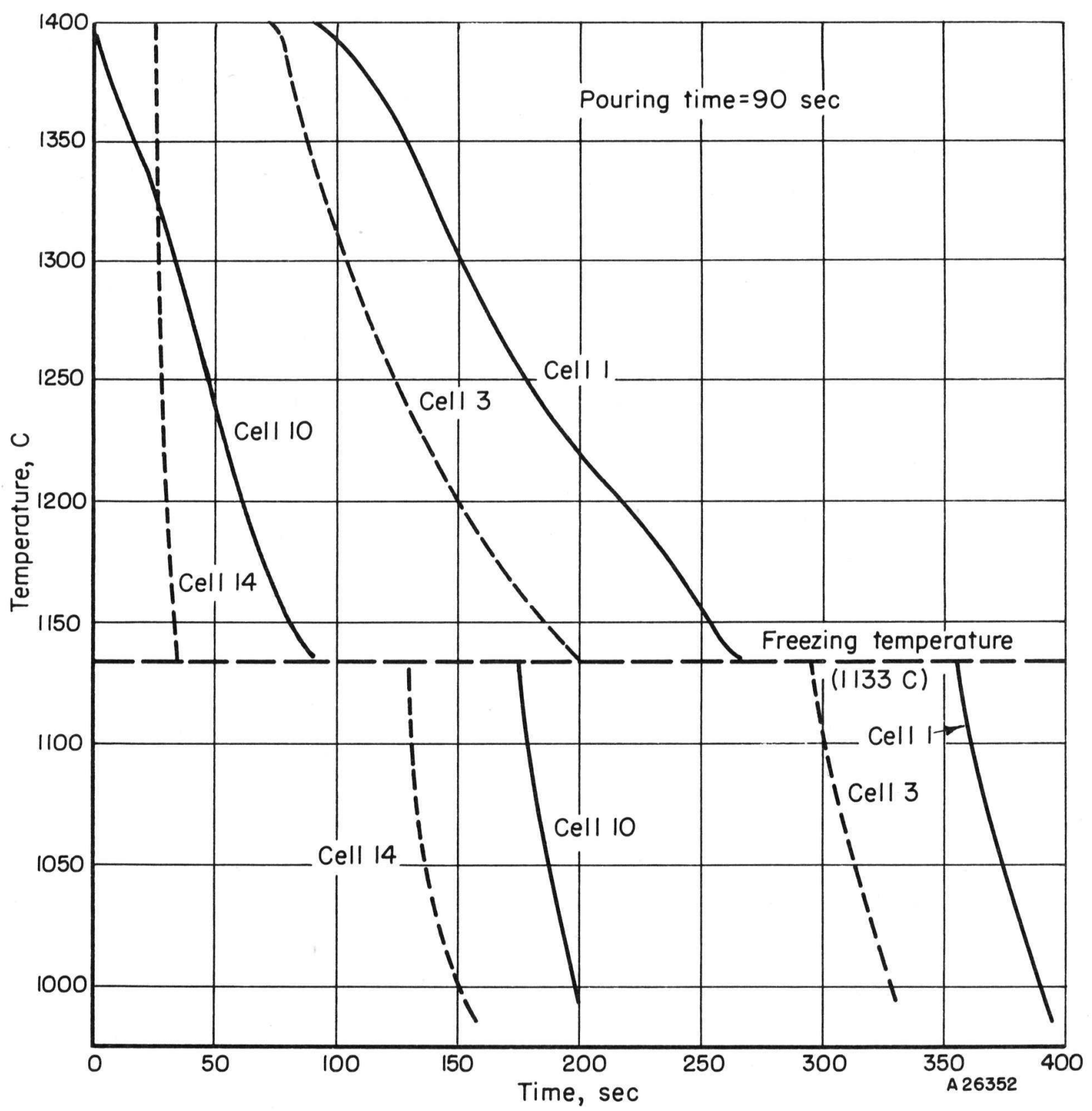

FIGURE 3. CALCULATED TEMPERATURE VERSUS TIME RELATIONSHIPS FOR 4 CELLS IN A CASTING COOLING FROM $1400 \mathrm{C}$, WITH THE HEAT OF FUSION BEING RELEASED AND THE COOLING OF UPPER CELLS DELAYED DUE TO A FINITE POURING TIME (90 SEC)

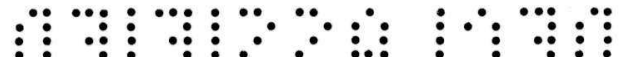

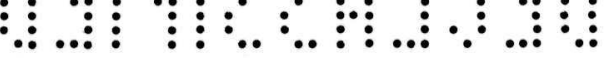


and in actual foundry practice it has been observed that under certain conditions a low pouring rate combined with high superheat promotes soundness. (78) The implication here is that entrapped liquid metal indicates the possibility of void formation.

The over-all solidification time for these two cases was 5.25 min and 6 min, the increase being primarily attributable to the differences in pouring times. It will later be seen that for the 75-cell model, in which the gapping at the interface is considered, the solidification time was found to be 13.2 min. This result is of interest because previous researchers have found, for example, that the freezing time for plates cast against chills is nearly doubled by air-gap formation. (39)

Another interesting effect observed with the simple model was an increase in the time required for the upper portions of the casting to solidify after the upper-mold-wall thickness was increased, this being attributed to the lower value of thermal conductivity used for the graphite as compared with uranium.

After these preliminary investigations, the more complex 75-cell model was developed. This model took into consideration the separation of the casting and mold walls, and the variation of thermal properties with temperature was included. The computer program devised for this model made use of a higher speed computer with magnetic-core storage; it is of interest to note that use of this equipment enabled making one cycle of computations in about the same time (28 sec) as required for the simpler 20-cell model.

Typical results obtained for the 75 -cell model are presented in Figures 4 through 8. Figure 4 shows the sequence of solidification found in a typical calculation for a production-size casting. In this case the initial pouring temperature was $1200 \mathrm{C}$, and the pouring time was $40 \mathrm{sec}$. The casting was found to solidify in $13.2 \mathrm{~min}$. Figure $4 \mathrm{~d}$ indicates that the last cell to solidify was below the top surface of the ingot, and this is interpreted to imply the formation of a void at that position. Interpreting this data as predicting a void at the exact location shown is questionable, however, since the top cell had solidified only 5 sec prior to completion of over-all solidification, and small errors in the computation could produce this effect. Of more interest is the solidification pattern at 11.6 min (Figure 4c); the long pipe existing at that time suggests the possibility of bridging at any of several locations, and this indication is not as dependent upon a close interpretation of final-stage calculations where the cells may be solidifying within a few seconds of each other.

The steplike appearance of the solidification fronts in Figure 4 is produced by the finite size of the cells. The actual front should have a parabolic appearance, and a model with many more cells would give a better approximation to this.

Figure 5 indicates the decay of temperatures for points located from the outer wall to the center line of the casting at a level one-third the length from the bottom of the casting. Several interesting phenomena are displayed by these curves. The cell at the interface (Curve A) reaches solidification temperature a short time ( 2 sec) after the liquid metal reaches that level. "Supercooling" before the heat of fusion is released is indicated. This supercooling is not of direct interest, however, since it is virtual and results from the methods of computation employed. The temperature is then arrested 
View shown is one half of a vertical section of a cylindrical casting with a cone-shaped bottom.
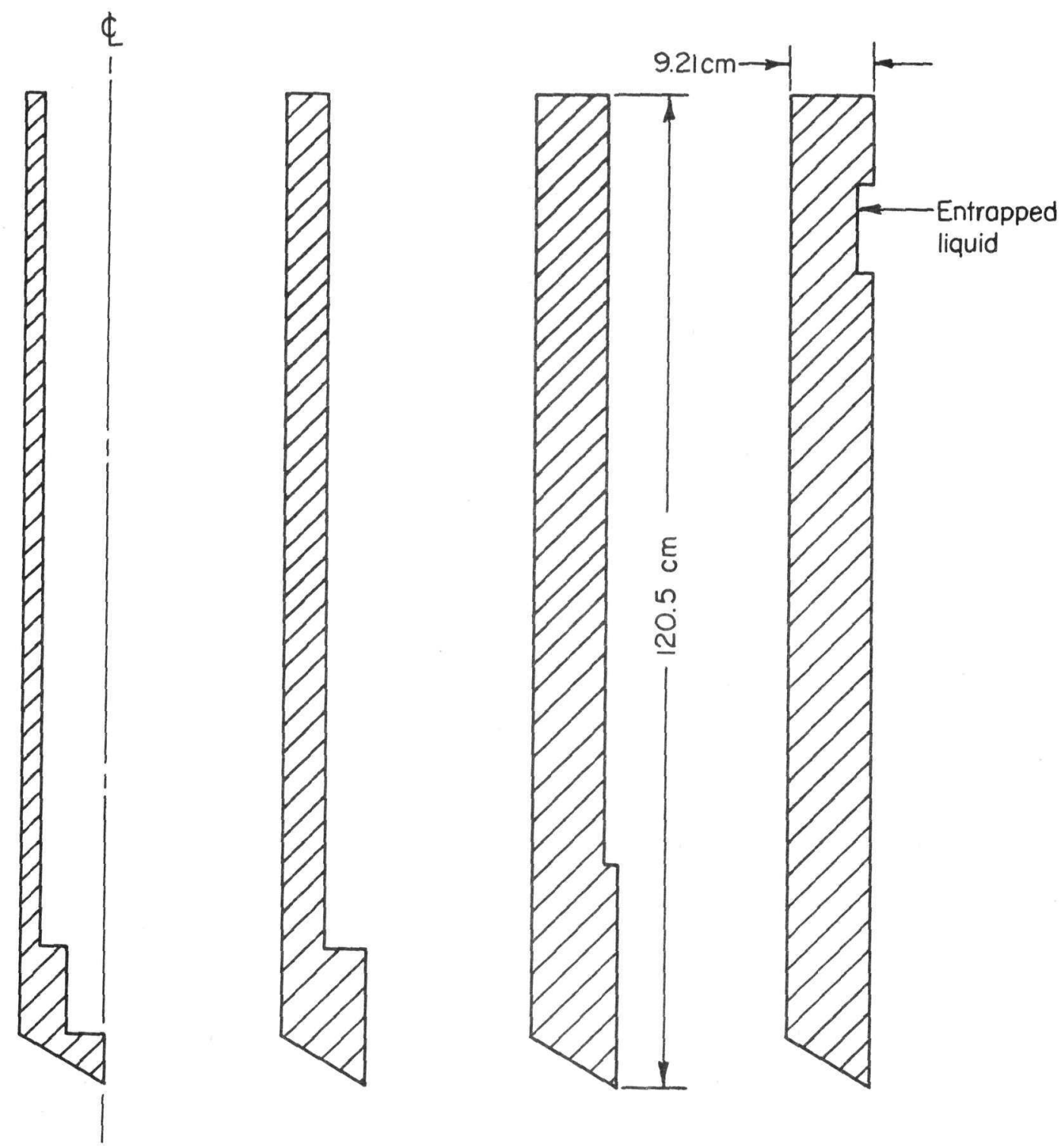

a. $2.8 \mathrm{Min}$.

b. $7.8 \mathrm{Min}$

c. $11.6 \mathrm{Min}$

d. 13.1 Min

Solidification completed in $13.2 \mathrm{~min}$

$A-28315$

FIGURE 4. CALCULATED GROWTH OF SOLID SKIN IN A SOLIDIFYING URANIUM CASTING AT VARIOUS TIMES AFTER START OF POUR 


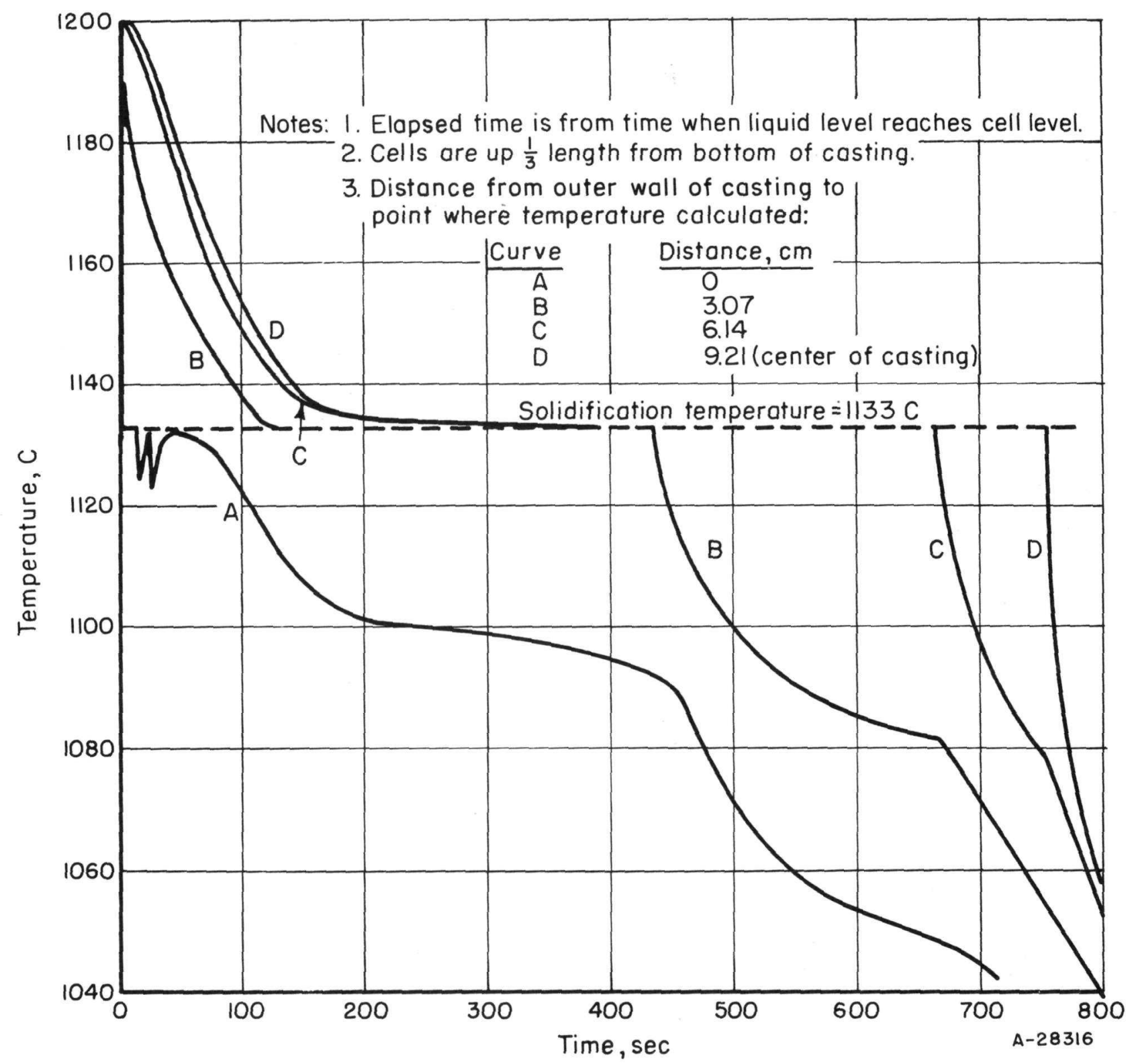

FIGURE 5. CALCULATED TEMPERATURE AS A FUNCTION OF TIME AT VARIOUS RADIAL POSITIONS IN A SEGMENT OF A SOLIDIFYING CYLINDRICAL URANIUM CASTING 


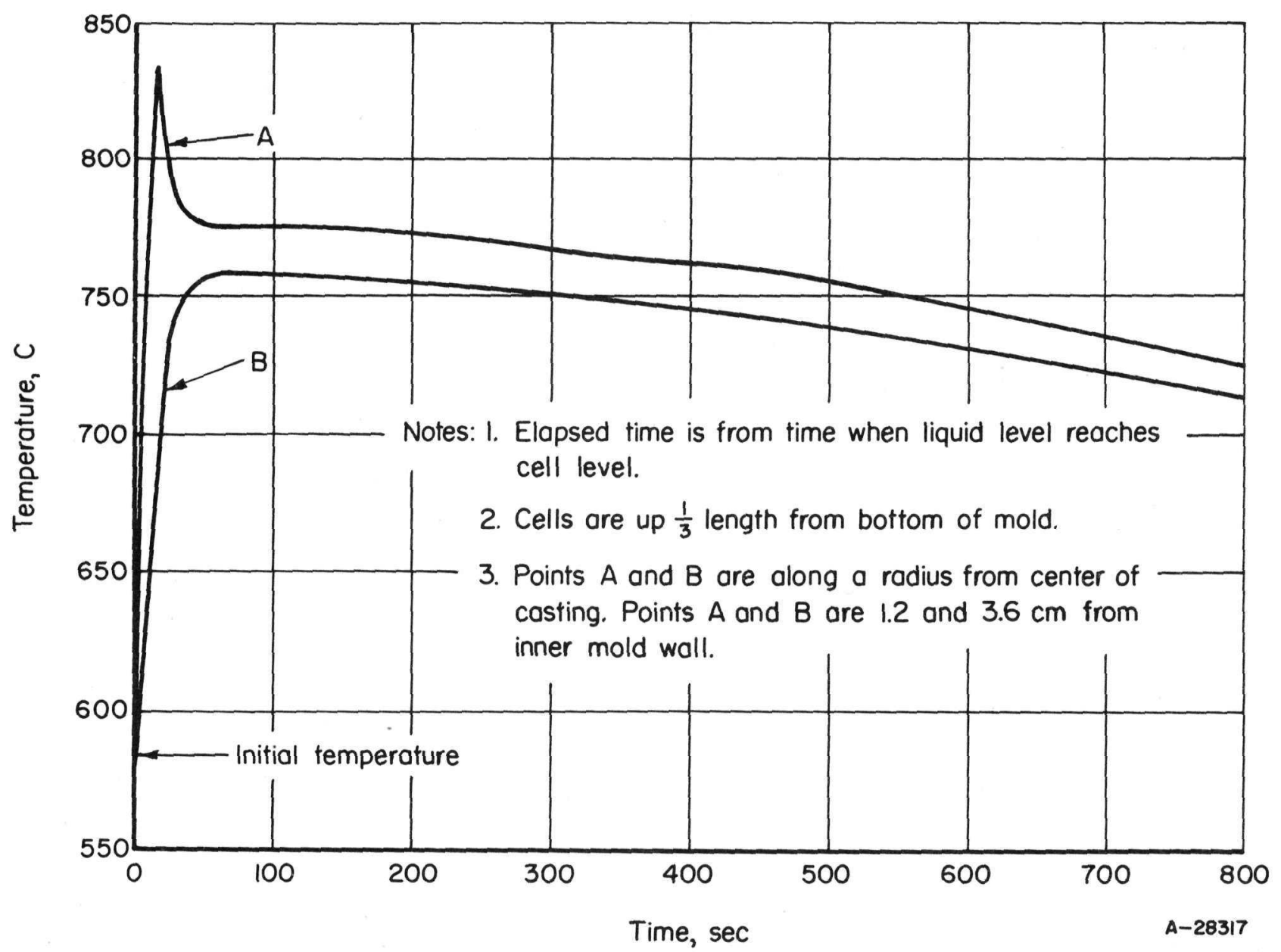

FIGURE 6. CALCULATED MOLD TEMPERATURES AS A FUNCTION OF TIME DURING THE SOLIDIFICATION OF A CYLINDRICAL URANIUM CASTING 

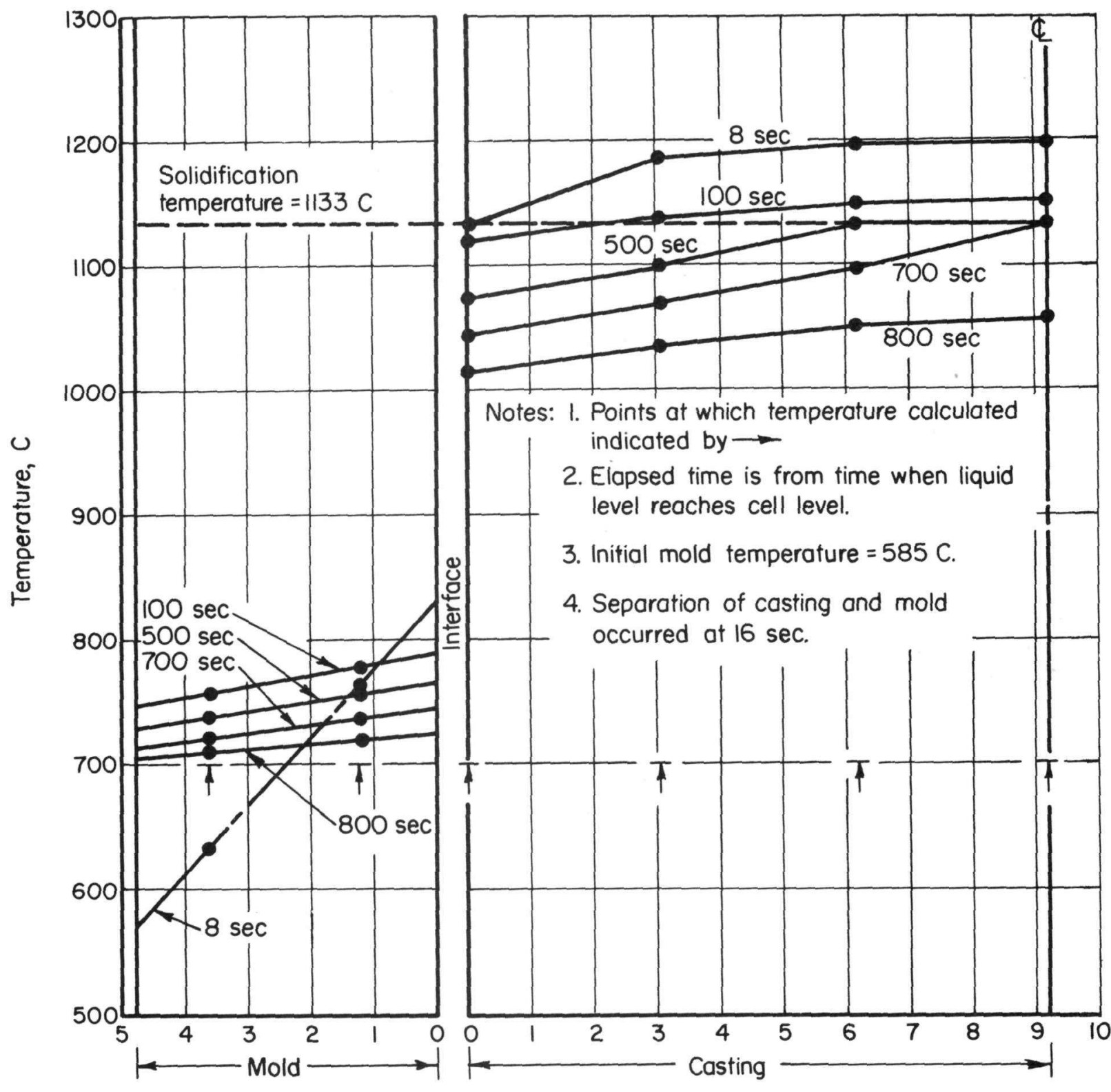

3. Initial mold temperature $=585 \mathrm{C}$.

4. Separation of casting and mold occurred at $16 \mathrm{sec}$.

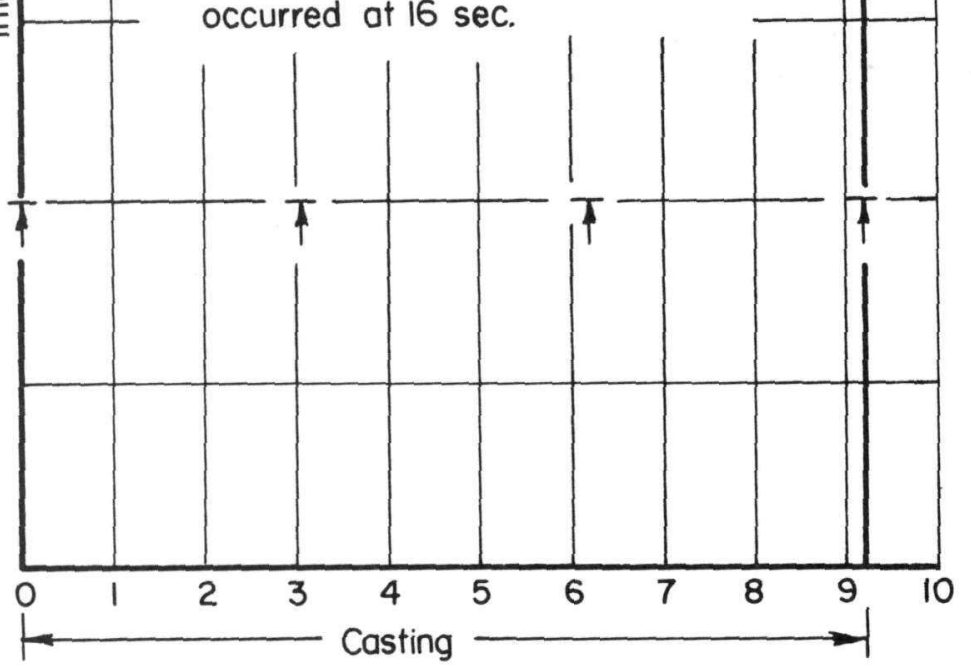

Distance From Interfoce, $\mathrm{cm}$

$A-28318$

FIGURE 7. CALCULATED TEMPERATURE AS A FUNCTION OF DISTANCE FROM INTERFACE AT VARIOUS TIMES DURING THE SOLIDIFICATION OF A CYLINDRICAL URANIUM CASTING 


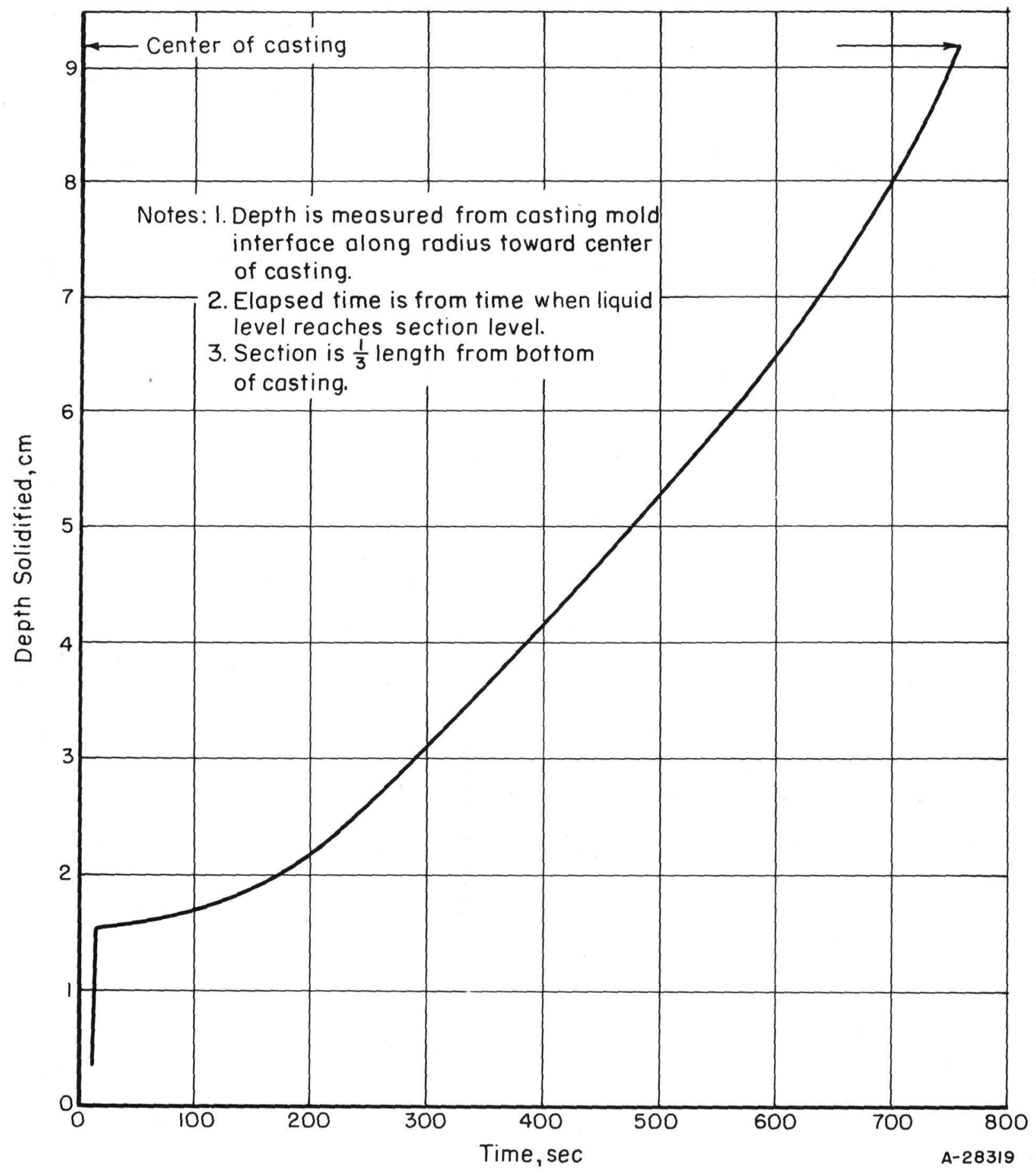

FIGURE 8. CALCULATED DEPTH SOLIDIFIED AS A FUNCTION OF TIME IN A CYLINDRICAL URANIUM CASTING 
at the melting value $(1133 \mathrm{C}$ ) until the heat of fusion has been released. After this, the temperature of the cell is found to increase slightly, this resulting from the reduced heat transfer caused by separation at the interface. Since the temperature is now slightly above the freezing value, the calculation program interprets this cell as not having solidified (since solidified cells are presumed to be at or below the solidification temperature), and the next computed temperature is based on a conductive heat transfer to the mold wall, this resulting in an abrupt drop in temperature; following this, the cell again slowly reheats, since a radiative heat transfer is again used because the heat of fusion of the cell has already been released. At a later time (about 10 sec after the first drop), the cell again exceeds the fusion temperature and another abrupt drop in temperature occurs. The cell then continues to cool in a normal fashion since the superheat of interior cells has been sufficiently decreased. Because the heat actually accumulated in the cell during the time its temperature is greater or equal to the freezing temperature is not enough to remelt the entire cell, this result is not to be taken literally, but the effect of this error on the over-all solidification pattern is presently considered negligible. It is of interest to note, however, that the existence of a similar mechanism in actual castings has been postulated; Paschkis $(66)$ has discussed the possibility of breathing taking place at the surface of a casting, this resulting from a decreased heat transfer at the surface after separation which permits interior heat to remelt the thin wall, the process continuing until interior temperatures have dropped sufficiently. Exact analysis of this will require a considerably better understanding of initial wall-growth and gap-formation phenomena. After the solidification of the wall cell is completed, the temperature is seen to decay at a lower rate since separation from the mold is established, and the inner mold wall has been heated.

The next inboard cell (Curve B) reaches solidification temperature at $130 \mathrm{sec}$, and a considerable increase in the time required to solidify is observed because of the reduced temperature gradients away from the interface. (Figure 7 indicates the temperature gradients existing at various times during the solidification of this horizontal segment of the casting.) When this cell completes solidification at $436 \mathrm{sec}$, an increase in the rate of cooling of the first cell to solidify is observed (see the "knee" of Curve $A$ at $450 \mathrm{sec}$ ). The effect is caused by use of a finite number of cells and the assumption of linear thermal gradients between them; increasing the number of cells would produce curves in which this knee effect would be decreased, and the curves obtained for the same positions would show less abrupt changes in decay rates.

Curves $C$ and D representing cells further inboard show comparable rates of cooling to $1133 \mathrm{C}$, and this is attributed to the uniform thermal gradients established after the initial rapid cooling at the wall. The appearance of the curves in Figure 5 is of interest in that there is a similarity with curves obtained by thermocouple measurements in previous researches $(70)$, although a detailed comparison is not appropriate because of differing casting conditions and materials.

Figure 6 is a plot of the time-temperature distribution for the two mold cells adjacent to the casting segment just discussed. The rapid temperature increase of the inner wall after contact with the liquid metal is evident, and a sudden drop in temperature follows the separation of the casting from the mold wall. The mold-wall temperature then decays at a lower rate as the solidification continues. The outer wall of the casting is found to heat less rapidly, and it reaches a maximum temperature about $60 \mathrm{sec}$ after the inner wall. 
Figure 7 indicates the temperature distribution across the same segment of the casting plotted in Figure 5 at various times from the start of pouring, and the corresponding mold-wall temperatures are included. The steep thermal gradients in the mold that exist immediately after pouring are apparent, and it is seen that the se rapidly disappear after mold-casting separation occurs and the outer mold wall has been heated. As explained before, the finite cell size distorts the thermal gradients in the casting when the entire cell is being held at $1133 \mathrm{C}$, and the effect of this distortion on computed results can be reduced by increasing the number of cells.

Since the position at which the temperature is computed for the inner wall mold cells is not on the face of the cell, it is apparent that using this temperature to compute radiative heat transfer from casting to mold is erroneous; however, using these interior points makes it possible to retain a finite thermal resistance between the walls of the casting and mold when they are in contact; if the effects of a mold wash are considered, the se points can be moved to the mold surface, and the finite thermal resistance of the mold wash can be introduced to determine the temperature gradient from the casting to the mold wall. A better value of the wall temperature might be obtained by extrapolation of the thermal gradients within the mold, but these refinements have been ignored for the present. Also, an increase in the number of cells would decrease the error.

Figure 8 is a plot of the depth solidified versus time. The high initial rate of wall growth caused by contact with the colder mold is evident, but after the gap is formed, the reduced rate of heat removal results in a considerably reduced rate of skin growth. As the wall thickens, the rate of wall growth is seen to increase. To explain this, note that the ratio of area to volume for a cylinder is

$$
2(1 / R+1 / L),
$$

$R$ being the radius and $L$ the length. This indicates that the ratio increases as $R$ decreases, so the area available to remove the heat content per unit volume is greater as the solid wall advances, and for a given thermal gradient an increased rate of growth should result.

Previous experimental researches of Pellini(72) have indicated that during most of the solidification period of chilled castings the interface temperatures are well below the solidification temperature. Figure 7 indicates that this condition is found for the calculated values. Bishop, Brandt, and Pellini(9) have suggested that the high temperature of the casting surface as compared with the mold - even though no mold wash is used - may exist before gapping, this indicating that close thermal contact never exists. Another interpretation might be that there is an initial good thermal contact, but this is for so short a time that the thermocouple does not respond because of its finite thermal capacity. The preliminary calculations indicate that the peak temperature of the inner mold wall is present for about $20 \mathrm{sec}$ (see Figure 6). Indications of gapping in experimental work will be established by thermocouple installations at or adjacent to the inner mold wall.

The preliminary results obtained appear reasonable in the light of past researches as to the time-temperature relationships in a solidifying casting. Further developments depend upon the checking and improvement of the model on the basis of experimental findings. The initial and boundary conditions and the thermal properties of the 
materials taking part in the heat removal from the casting must all be known if the analysis is to be correct. In fact, varying boundary or initial conditions can be used in the calculation, and their effects on the solidification of the casting can be observed, once the mathematical model is accurate. The attempted correlation of experimental and calculated results is the next phase of research.

\section{EXPERIMENTAL CONSIDERATIONS}

The results obtained to date appear to indicate that the approach discussed in the preceding paragraphs is sound and that it gives qualitative answers to the conditions present in uranium-casting procedure. The mathematical formulation must now be refined experimentally and then correlated with experimental data. This experimental portion can be considered as the second phase of the program which will be reported in detail in a subsequent topical report. Since some of the required physical-property values have to be determined, and since the necessary small-scale casting experiments have been planned, brief mention of this second phase will be made in the following paragraphs.

The experimental work can be logically divided into four tasks which are discussed in some detail. These tasks are:

(1) Determination of physical properties

(2) Verifying the thermal as sumptions

(3) Correlation of the tests

(4) Full-scale tests at NLO.

\section{Physical Properties}

Thermal-property data are necessary for the calculation of heat flow and the prediction of freezing rates in the chill casting of an ingot. It has been pointed out previously that in the present mathematical model there is a need for more knowledge of thermal properties of all of the materials concerned in the casting of uranium ingots. A search of the technical literature discussing previous investigations has not revealed sufficient information of pertinent properties at elevated temperatures. The actual values used in the mathematical model were either selected from the literature, based on extrapolated values using the published data as a base, or assigned a value based on the change that would normally be expected with change in temperature or phase. These values are listed in Appendix C.

The variation of the thermal properties with temperature is a primary concern in the tests, since an unsteady heat-flow process is known to exist as the casting solidifies. While the initial calculations consider this variation with temperature, the 
values used were obtained from values reported at some lower temperature and extrapolated to points near the melting temperature of the metal. Approximating these factors restricts the accuracy of the calculations in the model as such. Therefore, various properties of uranium and graphite materials need to be determined by experimental means.

The specific properties to be studied were chosen on the basis of their criticality in the mathematical formulation. These include:

(1) Thermal conductivity of uranium up to $2000 \mathrm{~F}$. (As-cast uranium samples taken from a large uranium casting in such a manner that the separate samples represent material orientated parallel and perpendicular to the long axis of the casting.)

(2) Thermal conductivity of liquid uranium up to $2500 \mathrm{~F}$.

(3) Thermal conductivity of graphite up to $2500 \mathrm{~F}$. (Again samples were taken in a manner to obtain information on material of different orientations relative to the ingot-mold axis.)

(4) Hemispherical total emissivity of graphite, mold-wash-coated graphite and uranium. (The surface of the uranium specimens was slightly oxidized to represent conditions found in practice.)

(5) Linear thermal expansion of graphite and uranium.

(6) Thermal resistance of mold wash.

(7) Specific heat of uranium up to $2500 \mathrm{~F}$.

The experimental studies required to determine these thermal properties are well under way. The determination of emissivity values is essentially complete and the determinations of thermal conductivity and linear thermal expansion of solid uranium and graphite are also nearing completion. The results of the emissivity measurements are described below.

\section{Hemispherical Total Emissivity}

Measurements of hemispherical total emissivity of the mold-wash-coated graphite and the oxidized uranium have been completed using the hole-in-tube method.

Specimens. Uranium and graphite specimens for the hole-in-tube method of measuring hemispherical total emissivity were tubes nominally $1 / 2 \mathrm{in}$. in diameter and $11 \mathrm{in.} \mathrm{long.} \mathrm{Annealed} \mathrm{sheet} \mathrm{uranium,} \mathrm{about} 0.010 \mathrm{in}$. thick, was oxidized on its surfaces and then rolled into a tube using a mandrel inside of a conforming tube. The graphite specimen was a machined tube having a wall thickness of about $1 / 8$ in. It was coated with a slurry of mold wash in a similar manner and thickness as used on graphite molds in practice. 
Method and Apparatus. The apparatus for the measurement of emissivities by the hole-in-tube method consisted of a cylindrical water-cooled vessel which could be evacuated to about $2 \times 10^{-5} \mathrm{~mm}$ of mercury. A Vycor window in one side permitted measuring specimen temperatures with an optical pyrometer. Corrections for the Vycor window were applied to the optical-pyrometer readings.

A 3/64-in. hole was drilled through one wall of the tubular specimen near the center of the specimen and two tantalum wire potential leads we re resistance welded to the uranium tube and pressed into holes in the graphite about 1 in. above and below the hole. Water-cooled current leads were affixed to each end of the tube and the assembly was placed in the water-cooled vacuum chamber.

Measurements were taken of the current flowing through the tube and the voltage drop across the potential wires. Optical-pyrometer readings were taken through the Vycor window of the black-body temperature through the hole in the specimen and the surface temperature beside the hole.

The total-emissivity values were determined using the following equation:

$$
\epsilon_{\mathrm{T}}=\frac{I V}{2 \pi r \ell \sigma \mathrm{T} 4}
$$

where

$$
\begin{aligned}
& \epsilon_{\mathrm{T}}=\text { hemispherical total emissivity } \\
& \mathrm{I}=\text { current through specimen, amp } \\
& \mathrm{V}=\text { potential drop across measured section, } \mathrm{v} \\
& \mathrm{r}=\text { radius of the specimen, } \mathrm{cm} \\
& \ell=\text { length of measured section, } \mathrm{cm} \\
& \sigma=\text { Boltzmann' s constant }=5.673 \times 10^{-12} \mathrm{w} /\left(\mathrm{cm}^{2}\right)\left(\mathrm{K}^{4}\right) \\
& T=\text { true (black body) temperature, } \mathrm{K} .
\end{aligned}
$$

Results. Figure 9 shows a plot of the experimental hemispherical totalemissivity values for oxidized uranium. The first-cycle heating curve shows an appreciably higher emissivity than does the first-cycle cooling or second-cycle heating. This probably results from some loss of oxide from the uranium surface during the first heating.

Figure 10 shows a plot of the experimental hemispherical total-emissivity values for graphite coated with mold wash. Values were obtained to temperatures near $1650 \mathrm{C}$ but are not shown above $1100 \mathrm{C}$ since a correction for thermal conductivity becomes increasingly important at higher temperatures in obtaining actual surface temperature. 


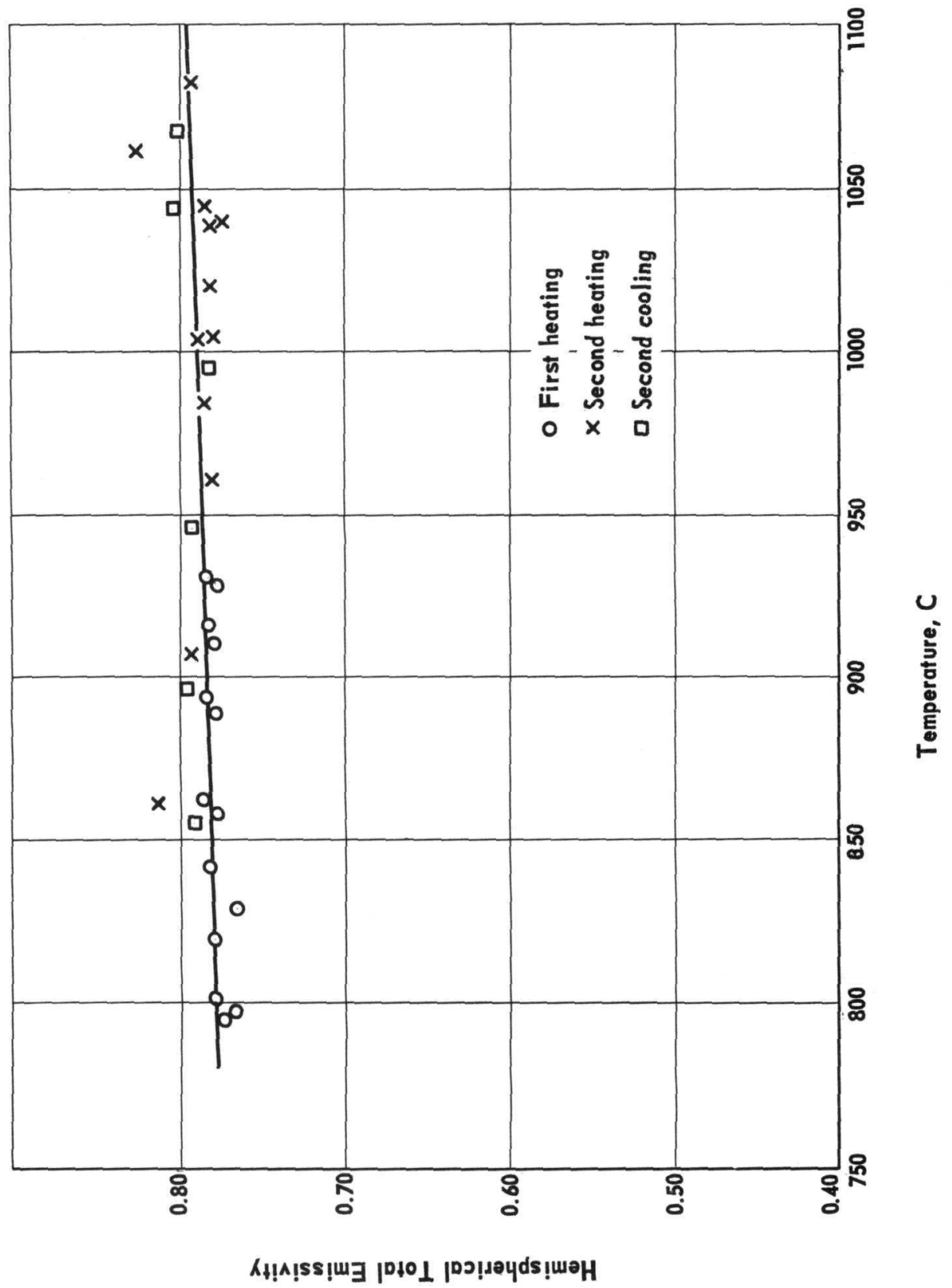

FIGURE 10. HEMISPHERICAL TOTAL EMISSIVITY OF GRAPHITE COATED WITH MOLD WASH

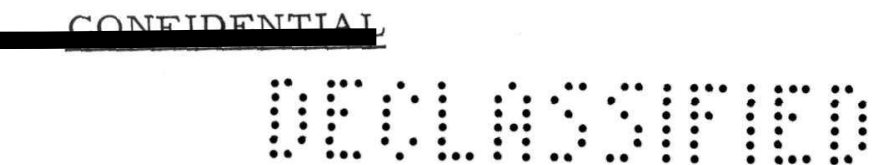


The high-temperature values will be reported when the high-temperature thermal conductivity of the graphite has been measured and the observed emissivity values corrected for this factor.

\section{Verification of Thermal Assumptions}

The mathematical description of the solidification process has been formulated by using a number of assumptions concerning thermal data. These assumptions are contained in the model and must be verified before the model can be proven as a whole. Some of the as sumptions are:

(1) The temperature of the mold wall during pouring

(2) The temperature of the inside surface of the furnace wall

(3) The temperature of the crucible above the top of the casting

(4) The existence of the gap between the metal and the mold.

For the formulation of the model it was assumed that the inside mold wall will remain at the temperature observed to exist just prior to pouring. This may be reasonable for the bottom section of the mold but, since the pouring takes place over an extended period, such an assumption may not be reasonable for the upper portion of the mold. This being the case, a properly thermocoupled experiment making use of a scale-model approach to the heat size will be set up to determine the temperature of the wall above the liquid level during pouring.

To measure the temperature of the inside mold surface as the metal is poured a number of thermocouples (of the platinum-platinum $10 \mathrm{w} / 0$ rhodium type) will be placed at intervals up and down the length of the mold wall. The thermocouples will be positioned in the mold in such a manner as to bring each hot junction flush with the mold surface. Placement of the thermocouples at various heights will allow the amount of heat absorbed at the mold surface to be recorded before the level of the liquid reaches it. Since the graphite material is a fair conductor, twin-bore ceramic tubing will be used to insulate the the rmocouple wires from the surrounding graphite. The beads of the thermocouples, however, will be left bare but adequately protected from the graphite by the ceramic tubes to insure the rapid response to temperature changes. This is necessary since the pouring time of the melts will be short. To utilize the thermocouples completely, readings will be taken before, during, and after pouring procedures. In doing this an entire the rmal history of the inside mold wall will be recorded during the solidification of the casting.

Two other temperatures have been assumed constant during the freezing time of the metal in the mathematical model. The se are the temperature of the inside furnace wall, and the temperature of the crucible above the casting. Allowing the furnace-wall temperature to remain constant is a fair assumption, since the furnace wall contains a cooling jacket with a constant rate of water flow which is sufficient to remove considerable quantities of heat. However, the assigned temperature may differ widely from the

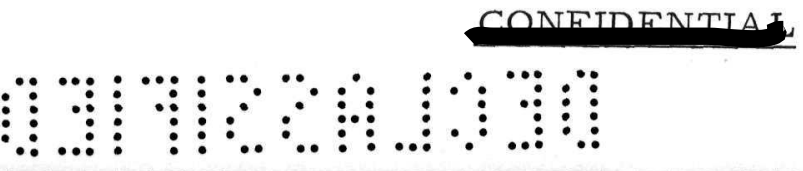


actual temperature during casting. This temperature measurement will be made by attaching a Chromel-Alumel thermocouple (with a bare hot junction at the point of contact) to the surface of the furnace wall. If the results of this test indicate that a temperature change is occurring, flow rates of the water may be altered to maintain a near constant temperature. Holding a known constant temperature at this point would be advantageous in making the theoretical calculations.

In the consideration of temperature above the casting after pour, it is known that a variation occurs, but the rate of temperature change has not been established. The fluctuations of temperatures in this area are believed to hold considerable importance in the over-all heat transfer phenomena since the top of the casting is known to freeze before complete solidification of the ingots has occurred. The forming of a solid layer of material may tend to cause a greater conductance of heat from the top of the ingot as the radiation properties of the material will change. By knowing if a drastic heating of the surroundings above the ingot occurs with an abrupt change in the physical state of the metal, a calculation of the actual heat transfer would be possible.

A thermocouple consisting of Alumel-Chromel wires will be attached to the bottom of the crucible just offset from the pouring orifice to record temperatures above the casting. A low-heat-capacity shield will be placed around the thermocouple to ensure that no side or back heat radiation is being measured.

Another phenomenon of great interest and one that must be determined experimentally is the time of formation and the position of the gap between the casting and. mold. It is presently believed that the formation of such a void in a chill casting results in a considerable decrease in the rate of heat absorption by the mold.

Paschkis (65) in his work with 4-in. steel plates concluded that air-gap formation would almost double the freezing time. Herne $(30)$ has calculated that a formation of a gap might reduce the rate of heat absorbed from 100 to $5 \mathrm{cal} /\left(\mathrm{cm}^{2}\right)(\mathrm{sec})$ with a mold used in the steel ingot industry. It is therefore important the formation of a gap in a chill casting be allowed for in any heat-transfer calculation, and it becomes most desirable to know the period during freezing that the gap is present.

In the present mathematical treatment the side surfaces of the casting and mold are assumed to remain in direct thermal contact until a fixed depth of the casting has solidified at which time instantaneous separation of the two occurs and heat transfer then continues as a radiative process. This assumption appears to be valid in light of previous investigations. MacKenzie and Donald (44) showed that deviations in the interface temperature occurred about $4 \mathrm{~min}$ after pouring 3 -ton steel ingots. Bishop, Brandt, and Pellini(9) found that effects of air-gap formation first occurred about 1 to $1-1 / 2$ min after pouring of 7-in. -square ingots. It therefore seems unlikely that the air gap takes place simultaneously at all points over the vertical surfaces of a chill casting. A more probable formation pattern would begin at a few locations and progress until a gap extends over the entire vertical surface.

As evidenced by the above discussion it is clear that the formation of gap between the casting and mold is important and that this condition must be accounted for in making heat-transfer calculations. It is also evident that measurement of the temperatures is one of the most suitable methods for determining the mechanisms of air-gap 
formation; therefore, direct experimental measurements will be taken in order to establish the progression of the gap formation during the casting of uranium.

In the attempt to measure the likely phenomenon of an air-gap formation between the mold and ingot a series of the rmocouples will be used. Placing pickups flush with the inner mold wall would be advantageous in that the liquid metal would not displace them during pouring. Another battery of thermocouples just far enough into the mold cavity to make contact with the metal at all times will provide temperatures on the metal side of the castings. The thermocouples in the liquid use the melt as an intermediate metal couple to record the temperature during solidification. The thermocouples would be platinum-platinum $10 \mathrm{w} / \mathrm{o}$ rhodium and would be exposed directly to the liquid. Since almost instantaneous freezing occurs at the surface of the casting little consideration need be given to the chemical reaction between the wires and the melt.

\section{Experimental Proof of the Model}

Once the model as formulated has been modified by experimental vertification of the assumptions, the most important phase of the experimental program follows; this is the actual experimental study which will bridge the gap between theoretical considerations and actual casting conditions. The objective of this phase of the program will be to determine the thermal gradients existing in the metal and mold through direct measurements of temperatures at various positions.

\section{General Experimental Procedure}

In order to accomplish the required objective, great care will be exercised in obtaining controlled experiments. Stringent material specifications will be maintained throughout the preliminary casting experiments in that materials utilized at NLO's production site will be used. This is advantageous in that thermal-property measurements determined for the small-scale casting investigations can be applied to large size castings. The material requirements are as follows:

(1) Molds shall be prepared from Speer's International Type 7100 graphite.

(2) The mold wash used will be the same as that used in production practice.

(3) The crucible wash used will be the same as that used in production practice.

(4) The metal charge will be as-reduced uranium.

No restrictions shall be placed on the type of graphite for the crucibles. 
All melts and castings will be made in a vacuum-induction-melting furnace. The charge will be melted in a graphite crucible at pressures of $1.0 \times 10^{-1} \mathrm{~mm}$ of mercury. Each melt will be held for a sufficient period ( 5 to $10 \mathrm{~min}$ ) at a temperature of $2550 \mathrm{~F}$ to insure that no large temperature difference exists in the melt before pouring. The metal will be bottom poured into cylindrical graphite molds that will produce an ingot $3 \mathrm{in}$. in diameter by $20 \mathrm{in.}$ long. A 5/8-in. -diameter pouring orifice will be used.

Thermocouples will be placed in the mold in the proper array and arrangement to give the desired data in each particular experiment. One proposed arrangement of thermocouples in the mold is seen in Figure 11. The diagram shows thermocouples placed at intervals along the outside and inside wall of the mold and others cantilevered into the mold cavity to near the center line of the major axis of the casting. The thermocouples that extend various distances from the inside mold surface are positioned to record temperatures on the metal side of the interface. Other thermocouples are placed such that temperatures on the graphite side of the interface may be recorded. These couples will be placed so that the hot junction is flush with the inside surface of the mold. The third the rmocouple that is in the mold cavity will record temperatures deep within the casting. In addition, thermocouples will be placed in the furnace above and below the area of the mold. The heads of the thermocouples will be encased in radiation shields to ensure reading the ambient temperatures. These thermocouples will record the temperature changes in the surrounding areas as the casting cools. A the rmocouple will be placed at the bottom of the crucible just away from the pouring orifice. This one will be used to measure temperatures the top of the casting "sees" as solidification of the liquid begins. Below the mold, another thermocouple will be attached to the steel mold support to detect the variation of temperatures at this point.

Since it is absolutely necessary that the temperatures of the metal-mold systems be recorded accurately the choice of thermocouples and the positioning of them are of the utmost importance. There are numerous difficulties encountered in obtaining accurate temperature readings at the desired positions.

In particular, the determination of the temperature at the metal-mold interface is one of extreme difficulty because of the probability of a gap formation occurring there. Ruddle $(80,81)$ attempted to measure the interface temperatures in nonferrous castings using two thermocouples, one molded into the sand with its hot junction just away from the mold surface and the other placed in the mold cavity, and bent at the tip to make contact with the first. Pellini and others $(27,35)$ adapted a similar method which showed good measurements on the metal side of the interface, but on the mold side they were somewhat low. This could be due to the size of hot-junction and conduction errors since temperature gradients in sand molds near the interface are extremely high. Another method, suggested by Atterton and Houseman(6), is one in which interface temperatures may be determined by allowing the casting to serve as an intermediate metal and form the hot junction with thermocouple wires placed in the mold cavity. This method would measure the temperatures on the metal side of the interface but shows no information for the mold side. Buley and Protheroe(15) also give a technique for using an intermediate metal thermocouple for measuring the temperature at the interface in steel castings. The technique has given reproducible results in line with theoretical expectations. 


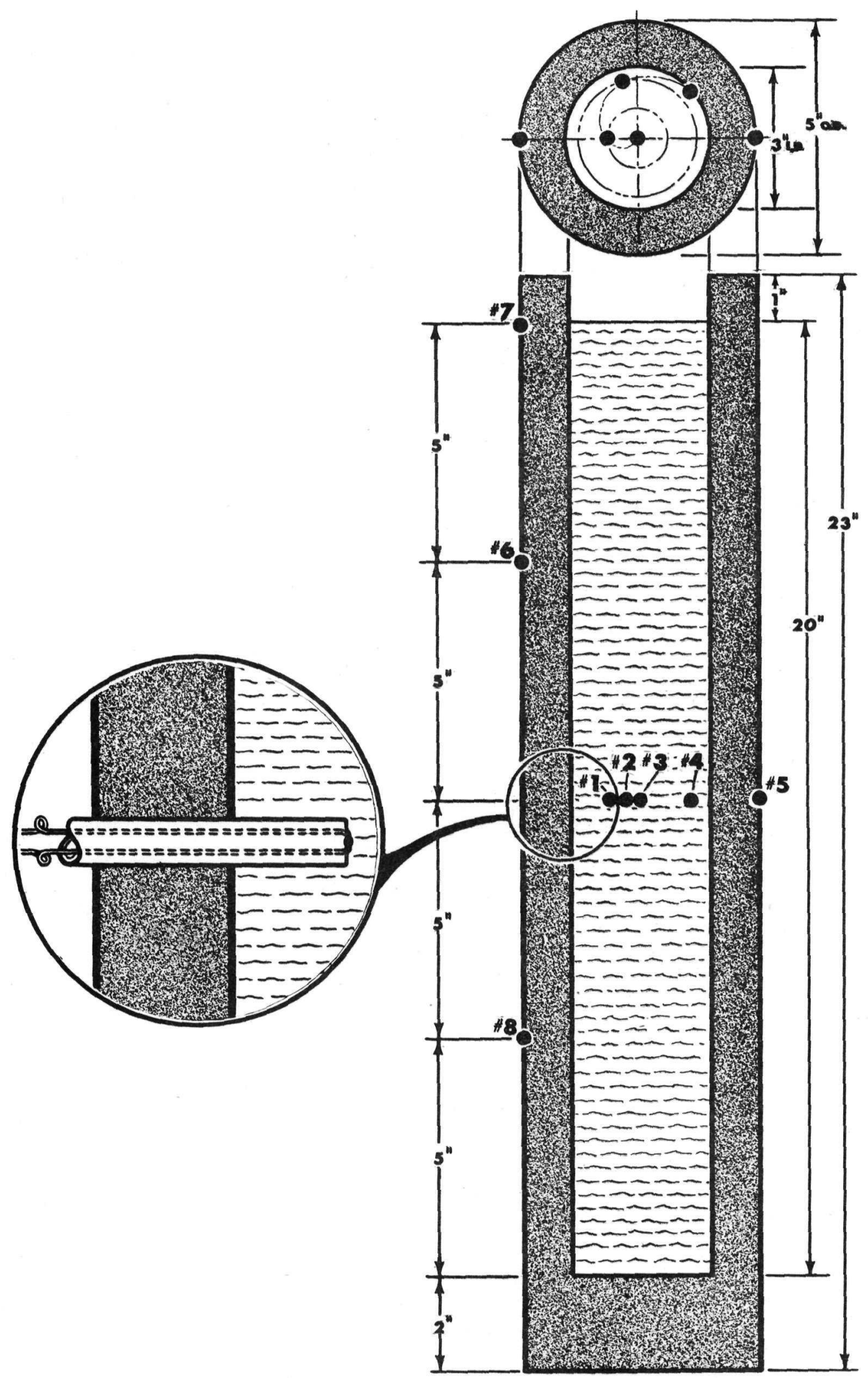

FIGURE 11. SCHEMATIC DIAGRAM OF PROPOSED GRAPHITE MOLD SHOWING THERMOCOUPLE EXPERIMENTAL CASTING

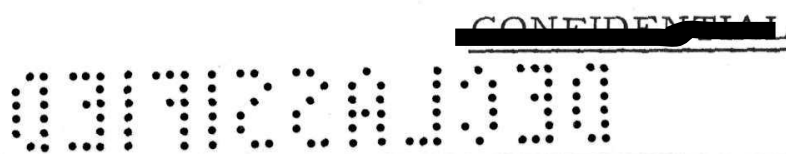


Thermocouples in the melt must be given adequate protection from attack by the hot liquid and must be rigidly supported to eliminate buoyancy effects. In the case of uranium metal, this is doubly important because of its reactivity and high density. The thermocouples should be as small as possible to keep distortions in the thermal conditions of the casting to a minimum and to ensure rapid response to temperature changes. A further consideration is that the couples need to be placed so that no end effects from freezing are encountered. These critical points and various factors are taken into consideration in attempting to record the temperatures after pouring of the metal.

The thermocouples to be used on the outside wall of the mold will be of the Chrome1-Alumel type as the temperature here is not expected to exceed $1700 \mathrm{~F}$. In the mold cavity itself thermocouples of platinum-platinum $10 \mathrm{w} / 0$ rhodium will be employed. These the rmocouples will be protected with a ceramic tube with the head of the couple exposed to the melt covered with $\mathrm{Al}_{2} \mathrm{O}_{3}$ cement. The exposure of the hot junction to the melt will be advantageous since a rapid response to temperature change is essential.

The wires for the thermocouples will be in the order of 28 gage and each couple will be calibrated before use. A multipoint recorder will be used to record the temperature at the outside mold surface and in the jacket of the furnace. This is a high precision recorder which has response of $4.5 \mathrm{sec}$ between points and is capable of reading temperature to within 1 per cent. Single-point curve drawing recorders will be attached to the thermocouples in the mold cavity. This type recorder has a response time of 1 sec at full scale and an accuracy to within 2 per cent. Although this type recorder sacrifices accuracy to some extent, it is capable of measuring and recording the rapid change in temperatures of the liquid during the filling of the mold and solidification of the metal.

\section{Specific Experiments}

An item which must be checked experimentally is the total solidification time of the casting. This will provide a good check as to the validity of the calculated results and will indicate the direction in which corrections should be made in the mathematical model. In a cylindrical casting it would be expected that some point along the center line will solidify last. This indicates that the rmocouples displaced along the center line would be of value in determining the time of final solidification and the position of the last remaining molten zone. Thermocouples will be cantilevered into the mold cavity to the center-line axis at various vertical heights above the bottom of the mold. The thermocouples will be platinum-platinum $10 \mathrm{w} / 0$ rhodium and the wires will be encased in round twin-bore ceramic tubes out to the hot-junction bead. The bead will be left exposed in order that measurements may be taken with the highest degree of response. As total solidification time will be rather short, particularly in small melts, it is believed that corrosion of the hot junction by the liquid metal will not occur at the $2500 \mathrm{~F}$ temperatures. The stability of the thermocouples at these points is always a consideration of some doubt. However, ceramic protection tubes that will be used have been observed to have good resistance to thermal shock and good resistance to shock of the moving liquid as it enters the mold cavity. An examination by sectioning

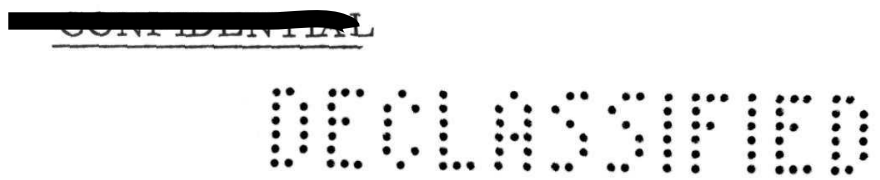


the ingots will disclose the condition of the thermocouples after solidification and indicate if changes should be made in the the rmocouple procedure. These thermocouples would also indicate the rate at which the casting is poured, a factor having considerable influence on the progress of solidification. A further check on the rate of pour will be made by clocking the time required for the crucible to empty. This will be done by observing the melt flowing out of the crucible from an observation glass at the top of the furnace. An adequate thermocouple installation will reveal whether the melt is filling the mold with or without a substantial heat loss.

The development of cooling curves, as determined by the mathematical analysis and by direct measurements, will be the means of correlating the results obtained. This will consist of plotting temperature readings with time to show the rate of change in temperature for any one position in the casting. Examination of a number of the se curves as the ingot cools will allow the progress of the freezing fronts to be followed and subsequently the manner by which feeding of the liquid is occurring. Once the experimental data have been analyzed, comparisons of the cooling curves will be made. Any variation in the temperature decays will be noted. As these variations are found and evaluated, changes will be made in the theoretical mathematical model to account for them.

\section{Possible Experiments to Be Conducted at NLO}

In regard to the experimental work, information available or obtainable at the NLO site would contribute much to the evaluation of the se variables. Whether the information cited is required or merely desired, cannot be fully evaluated at this time. However, some examples of the kinds of information that may be desired and their significance are presented below.

Solidification of the Production-Size Ingot. If the total time between actual pouring and complete solidification of the ingot is known, one important criterion will be available for judging the validity of the calculated results. This information is difficult to determine; however, one method of obtaining it would be by thermocouples placed in the mold cavity before pouring.

Inlet and Outlet Mold-Tank Cooling-Water Temperatures. If data on the rate of flow of cooling water and the inlet and outlet transient temperatures were obtainable from the time of pouring until solidification is completed, then the quantity of heat given up by the mold surface through radiation to the cooling jacket could be calculated. Since radiative heat transfer depends upon the temperatures of surfaces that the mold "sees", it is also important to establish the temperatures of the inner wall of the furnace shell.

Temperature Differences at the Mold Wall-Uranium Interface. Information of this nature presents experimental difficulties. However, it is important in two regards: (1) the formulation of equations in the basic mathematical model depends upon the 
heat-flow process occurring at this interface, and temperature data will help to establish the nature of this basic mechanism; (2) the se same data could give additional information as to the time and location of mold-ingot parting. While experiments are planned on a laboratory scale at Battelle, obtaining similar data for a production casting would be informative in evaluating the effects of ingot size on this variable.

Another assumption made in the mathematical model used to date is that the temperature of the crucible bottom remains constant throughout solidification. Again, since radiative heat loss from the top of the casting depends upon this temperature, accurate data would establish more realistic assumptions.

\section{CONCLUSIONS}

The computations made with the 75-cell model have produced logical results according to the assumptions made to develop the mathematical model, e.g., the sudden drop of the inner-mold-wall temperature after separation from the casting appears reasonable. The solidification sequence in the cylindrical casting shows the solidified uranium developing the expected cup shape in the initial stages. For one set of conditions for casting a production-size ingot, a total solidification time of $13.2 \mathrm{~min}$ has been calculated, and this is in the expected range of values; if the calculated time had been several hours or a few seconds, then the method of calculation would be suspect.

The se and similar considerations indicate that the results obtained by this mathematical model are in qualitative agreement with past research determining the time-temperature relationships in a solidifying casting. It appears worthwhile to further refine and develop the model and to attempt correlation with actual casting experiments specifically designed for this. Such experiments will provide an empirical test of the convergence of the calculated solution to the real situation. Modification of the assumptions used to develop the model may be dictated by such experimental evidence, and it is possible that the number of cells used to represent the casting will have to be increased in order to obtain a sufficiently accurate solution.

The method of analysis indicates the need for experimentally establishing the thermal properties of all materials participating in the removal of heat from the casting, excepting those outside the boundaries established for the calculations. Explicit knowledge of such factors as the initial superheat, rate of pour, initial mold temperatures, and environmental temperatures is required. An objective of further investigations is to examine the effect of changes in the se and other factors on the solidification pattern of the casting.

The mathematical model was specifically developed for a cylindrical uranium ingot cast in a graphite mold, but other mold and unalloyed casting materials can be considered by altering the the rmal properties accordingly. Size variations of the casting can be considered, and the length-to-diameter ratio can be varied within reasonable limits. These considerations make it possible to adopt the present model to experimental-size castings. 
Further developments of this method of analysis are worthwhile and of potential value in assisting the uranium foundryman in developing methods for controlling the solidification of castings.

\section{ACKNOW LEDGMENT}

The authors wish to acknowledge the interest exhibited by the National Lead Company of Ohio in implementing this research. Particular acknowledgement is due C. Polson, H. Davis, and D. Cavett of National Lead for their active and continuing participation.

BLF:ELF:CKF:AL:BLS:RFD/mrm/apo/bjw 
ConIEENIIAL

APPENDIX A

BIBLIOGRAPHY

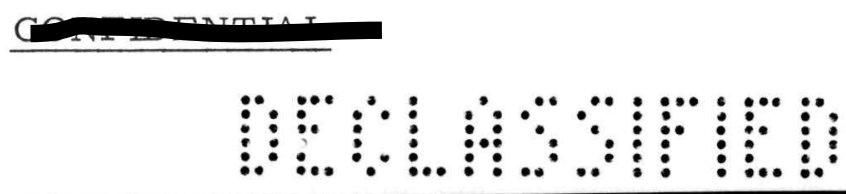


$\mathrm{A}-1$

\section{APPENDIX A}

\section{BIBLIOGRAPHY}

(1) Adams, C. M., Jr., and Taylor, H., "Flow of Heat From Sand Castings by Conduction, Radiation, and Convection", Massachusetts Institute of Technology, Cambridge, Massachusetts (date not available).

(2) Adams, C. M., Jr., and Taylor, H., "Fundamentals of Riser Behavior", Trans. Am. Foundrymen's Soc., 61, 686 (1953).

(3) Adams, C. M., Jr., and Taylor, H., "A Simplified Analysis of Riser Treatments", 1952 Am. Foundrymen's Soc. Annual Meeting, Preprint No. 52-81.

(4) Alexander, B. H., "Solidification of Ingots", 1950 Am. Foundrymen's Soc. Annual Meeting, Preprint No. 50-3.

(5) Am. Foundrymen's Assoc. Committee Report, Trans. Am. Foundrymen's Assoc., 55, "Report of Heat Transfer Committee", 53 (1947).

(6) Atterton, D. V., and Houseman, D. H., "Measurement at the Metal-Mold Interface", Nature, 171, 980 (1953).

(7) Batty, G., "Controlled Directional Solidification", Trans. Am. Foundrymen's Assoc., 42, 237 (1934).

(8) Batty, G., "The Influence of Temperature Gradients in the Production of Steel Castings", Trans. Am. Foundrymen's Soc., 43, 75 (1935).

(9) Bishop, H. F., Brandt, F. A., and Pellini, W. S., "Solidification Mechanism of Steel Ingots", Trans. AIME, 194, 44 (1952).

(10) Bishop, H. F., Myskowski, E. T., and Pellini, W. S., "The Contribution of Riser and Casting End Effects to Soundness of Cast Steel Bars", Trans. Am. Foundrymen's Assoc., 59, 171 (1951).

(11) Bishop, H. F., and Pellini, W. S., "Solidification of Metals", Foundry, 80 (2), 87 (1952).

(12) Brandt, F. A., Bishop, H. F., and Pellini, W. S., "Solidification of Various Metals in Sand and Chill Molds", Trans. Am. Foundrymen's Soc., 62, 646 (1954).

(13) Briggs, C. W., and Gezelius, R. A., "The Rate of Skin Formation", Trans. Am. Foundrymen's Assoc., 43, 274 (1935).

(14) Briggs, C. W. , The Metallurgy of Steel Castings, McGraw-Hill Book Company, New York (1946), Chapter VI, "The Solidification of Steel Castings", p 183.

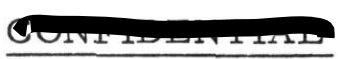




\section{$A-2$}

(15) Buley, P. R., and Protheroe, H. T., "Adherence of Sand on Steel Castings", J. Iron Steel Inst., 167, 647 (1951).

(16) Carslaw, H. S., and Jaeger, J. C., Conduction of Heat in Solids, Clarendon Press, Oxford (1.947).

(17) Chalmers, B., "Melting and Freezing", Trans. ASME, 200, 519 (1954).

(18) Chvorinov, N., "Control of Solidification of Castings by Calculation", Foundry Trade J., 61, 95 (1939).

(19) Chvorinov, N., "Theory of the Solidification of Castings", Giesserei, 27, 177 (1940).

(20) Cuthbert, F. L., and Shaw, W. E., "A Hot Subject: Casting Uranium", Modern Castings, 30 (4), 32 (1956).

(21) Duma, J. A., and Brinson, S. W., "Application of Controlled Directional Solidification to Large Steel Castings", Trans. Am. Foundrymen's Assoc., 48, 225 (1940).

(22) Dunphy, R. P., and Pellini, W. S., "Solidification of Gray Iron in Sand Molds", Trans. Am. Foundrymen's Soc., 59, 425 (1951).

(23) Dusinberre, G. M., Numerical Analysis of Heat Flow, First Edition, McGraw-Hill Book Company, New York (1949).

(24) Emmons, H. W., "The Numerical Solution of Heat Conduction Problems", Trans. ASME, 65, 607 (1943).

(25) England, F., and Croft, H., "Radiation Configuration Factors Using Light in Furnace Models", Trans. ASME, 64, 691 (1942).

(26) Field, A. L., "Temperature Distribution in Ingot and Mold in Steel Practice", Trans. Am. Soc. Steel Treating, 11, 264 (1927).

(27) Grice, V., and Berry, J. T., "Development and Application of a Foundry Test for Assessing Shrinkage Behavior in Grey Cast Iron", Foundry Trade J., 101 (2079), 159 (1956).

(28) Hawkins, G. A., and Agnew, J. T., "The Solution of Transient Heat Conduction Problems by Finite Differences", Purdue Univ., Eng. Bull. Ext. Ser., Research Ser. No. 98, Lafayette, Indiana (March, 1947).

(29) Heggie, R. G., "Experiments on the Crystallization of Ingots", Trans. Faraday Soc., 29, 707 (1933).

(30) Herne, H., Brit. Iron Steel Research Assoc., Report P/C, 44 (1949).

(31) High Temperature Technology, Edited by I. E. Campbell, John Wiley \& Sons, Inc., New York (1956), "Temperature and Its Measurement; Pyrometry by Radiation Methods" (P. H. Dike), p 335. 


\section{A-3}

(32) Hughes, I. C. H., "Solidification Sequences and Their Significance", Brit. Cast Iron Research Assoc., Research Department (Research Conference, Ashorne Hill, November 29-December 1, 1954), Research Report No. 399, p 518.

(33) Jackson, R., et al., "Variable Heat Flow in Steel", J. Iron Steel Inst., 150, 211 (1944).

(34) Jakob, Max, Heat Transfer, Vols 1 and 2, John Wiley and Sons, Inc., New York, (1949, 1957).

(35) Johnson, W. H., Bishop, H. F., and Pellini, W. S., "Velocities and Volume Rates of Metal Flow in Gating Systems", Trans. Am. Foundrymen's Assoc., 62, 242 (1954).

(36) Katz, J. J., and Rabinowitch, E., The Chemistry of Uranium, McGraw-Hill Book Company, New York (1951), Chapter 5, "Physical Properties of Uranium".

(37) Kaufmann, A. R., "Visit by Dr. Finniston of Harwell and Drs. Cunningham and Perry of the Canadian Bureau of Mines to Massachusetts Institute of Technology", WASH -339 (1953). Declassified.

(38) Keller, W. H., "Preliminary Report on Vacuum Casting of Uranium Into Heated Molds", NYO-1 327 (1951). Declassified.

(39) King, T. B., "Solidification of Steel", Iron and Steel, 479 (Oct., 1953).

(40) Kreith, F., and Romie, F. E., "A Study of the Thermal Diffusion Equation With Boundary Conditions Corresponding to Solidification or Melting of Materials Initially at the Fusion Temperature", Proc. Phys. Soc., 68, Section B, Part 5, 277 (May, 1955).

(41) Lewis, D. M., "Techniques for the Investigation of Thermal Conditions in Continuous Castings", J. Inst. Metals, 82 (8), 395, (Apr., 1954).

(42) Lightfoot, N. M. H., "The Effect of Latent Heat on the Solidification of Steel Ingots", Section V of Third Report on the Heterogeneity of Steel Ingots, J. Iron Steel Inst., 119-120, 364 (1929).

(43) Loria, E. A., "Solidification and Segregation in Killed Steel Ingots", Blast Furnace and Steel Plant, $\underline{40}, 410$ (1952).

(44) MacKenzie, I. M., and Donald, A., "The Distribution of Temperature in Ingot Molds and Its Relation to Ingot Structure", J. Iron Steel Inst., 166, 19 (1950).

(45) Marburg, E., "Accelerated Solidification in Ingots: Its Influence on Ingot Soundness", Trans. AIME, 197, 157, (Feb., 1953).

(46) Matuschka, B., "Solidification in Open-Topped and Closed-Top Ingot Molds", J. Iron Steel Inst., 137, 109 (1938). 
$\mathrm{A}-4$

(47) McAdams, W. H., Heat Transmission, Third Edition, McGraw-Hill Book Company, New York(1954).

(48) McCance, A., "Ingots and Ingot Molds", J. West Scot. Iron Steel Inst., 37, 109 (1929-1930).

(49) Mickley, H. S., Sherwood, T. K., and Reed, C. E., Applied Mathematics in Chemical Engineering, Second Edition, McGraw-Hill Book Company, New York (1957).

(50) Modern Mathematics for the Engineer, Edited by E. F. Beckenbach, McGrawHill Book Company, New York (1956), "Hyperbolic Partial Differential Equations and Applications", R. Courant, p 92.

(51) Nelson, L. H., "Solidification of Steel in Ingot Molds", Elec. Furnace Steel Proc. (1953).

(52) Nelson, L. H., "Solidification of Steel in Ingot Molds", Trans. ASM, 22, 193 (1934).

(53) Nichols, R. W., "Uranium and Its Alloys", Nuclear Engineering, 2, 355 (Sept., 1957).

(54) Numerical Methods of Analysis in Engineering, arranged by L. E. Grinter, Macmillan Company, New York (1949), "The Problems in Building Heating Solved Numerically", (G. M. Dusinberre), Chapter 7, p 104.

(55) O'Brien, G. G., Hyman, M. A., and Kaplan, S., "A Study of the Numerical Solution of Partial Differential Equations", J. of Math. and Phys. 29, 223 (1951).

(56) Oppold, W. A., "A Report on the Casting of Slugs in Graphite Molds", NYO-5102 (Apr., 1945). Declassified.

(57) Paschkis, V., "Comparative Solidification Studies", 1949 Am. Foundrymen's Soc. Annual Meeting, Preprint No. 49-42.

(58) Paschkis, V., "The Foundryman and Heat Transfer", 1949 Am. Foundrymen's Soc. Annual Meeting, Preprint No. 49-43.

(59) Paschkis, V., "Heat Flow Problems in Foundry Work", Trans. Am. Foundrymen's Soc., 52, 649 (1944).

(60) Paschkis, V., "The Heat and Mass Flow Analyzer - A Tool for Heat Research", Metal Progr., 52, 813 (Nov., 1947).

(61) Paschkis, V., "Heat Transfer - A Foundryman's Tool", Trans. Am. Foundrymen's Soc., 57, 310 (1949). 
A -5

(62) Paschkis, V., "Influence of Dry Sand Conductivity on Rate of Freezing of Steel Slabs", $1950 \mathrm{Am}$. Foundrymen's Soc. Annual Meeting Preprint No. 50-7.

(63) Paschkis, V., "Solidification of Cylinders", Trans. Am. Foundrymen's Soc., 61, 142 (1953).

(64) Paschkis, V., "Solidification of Finite Cylinders", Trans. Am. Foundrymen's Soc., 62 , 48 (1954).

(65) Paschkis, V., "Studies on Solidification of Castings", Trans. Am. Foundrymen's Assoc., 53, 90 (1945).

(66) Paschkis, V., "Theoretical Thermal Studies of Steel Ingot Solidification", Trans. ASM, 38, 117 (1947).

(67) Paschkis, V., and Baker, H. D., "A Method for Determining Unsteady-State Heat Transfer by Means of an Electrical Analogy", Trans. ASME, 105 (Feb., 1942).

(68) Paschkis, V., and Hlinka, J. W., "Some Generalized Solidification Studies", Heat and Mass Flow Analyzer Laboratory Research Laboratories, Department of Mechanical Engineering, Columbia Univ., Tech. Rept. No. 4, Project 127 (Jan. 16, 1957).

(69) Pellini, W. S., "Factors Which Determine Riser Adequacy and Feeding Range", Trans. Am. Foundrymen's Soc., 61, 61 (1953).

(70) Pellini, W. S., "Foundrymen Can't Know Too Much About Practical Heat Transfer", Am. Foundryman, p 69 (Feb., 1953), p 59 (March, 1953).

(71) Pellini, W. S., "Practical Heat Transfer", Trans. Am. Foundrymen's Soc., 61, $603(1953)$.

(72) Pellini, W. S., "Solidification of Various Metals in Ingot and Sand Molds", Am. Inst. Mining, Met., Petrol. Engrs., Preprint, Electric Furnace Steel Conference, Chicago, Illinois (Dec. 5-7, 1956).

(73) Price, P. H., and Slack, M. R., "Stability and Accuracy of Numerical Solutions of the Heat Flow Equation", Brit. J. Appl. Phys., 3, 379 (1952).

(74) Rengstorff, G.W.P., and Lownie, H. W., Jr., "Casting Large Ingots of Uranium", Metal Progr., 72 (3), 76 (Sept., 1957).

(75) Reynolds, J. A., and Price, A., "Solidification Mechanism", Foundry Trade J., 99, 31 (1955).

(76) Reynolds, J. A., and Tottle, C. R., "The Nucleation of Cast Metals at the Mold Face", J. Inst. Metals, 80, 93 (Oct., 1951). 


\section{A-6}

(77) Ruddle, R. W., "A Preliminary Study of the Solidification of Castings", J. Inst. Metals, 77, l(1950).

(78) Ruddle, R. W., The Solidification of Castings, Inst. Metals (London) (1957).

(79) Ruddle, R. W., and Mincher, A. L., "Thermal Properties of Some Non-Metallic Mold Materials", J. Inst. Metals, 76, 43 (1949-1950).

(80) Ruddle, R. W., "A Preliminary Study of the Solidification of Castings", J. Inst. Metals, 77, 1 (1941).

(81) Ruddle, R. W., and Mincher, A. L., "The Influence of Alloy Constitution on the Mode of Solidification of Sand Castings", J. Inst. Meta1s, 78, 229 (1950-51).

(82) Russell, H. W., "Principles of Heat Flow in Porous Insulators", J. Am. Ceram. Soc. , 18, 1 (1935).

(83) Saitô, S., "On the Distribution of Temperature in Steel Ingots During Cooling", Sci. Repts., Tôhoku Imp. Univ. (Japan), 10, 305 (Dec., 1921).

(84) The Reactor Handbook, Vol 3, Section 1, AECD-3647 (1955), "Uranium and Its Alloys" (H. A. Saller), p 383.

(85) Sargant, R. J., and Slack, M. R., "Internal Temperature Distribution in the Cooling and Reheating of Steel Ingots", J. Iron Steel Inst., 177, 428 (Aug., 1954).

(86) Schaaber, Otto, "Heat Flow in Metal Melts in the Immediate Vicinity of the Liquid-Solid Phase Boundary", Z. Metallkunde, 43, 251 (1952). [Abstract and Comments by Prof. B. Floyd Brown, Am. Foundryman, p 90 (Apr., 1954)] .

(87) Schneider, P. J., Conduction Heat Transfer, Addison-Wesley Publishing Company, Inc., Cambridge, Massachusetts (1955).

(88) Schwartz, H. A., "How Fast Do Metals Freeze", Foundry, 72 (12), 80 (1944).

(89) Schwartz, H. A., "Solidification of Metals", Trans. Am. Foundrymen's Soc., $53,1(1945)$.

(90) The Solidification of Metals and Alloys, AIME, Metallurgical Engineers (1951).

(91) "Solidification Rate of Cast Iron", Committee Report, Foundry Trade J., 94, 59 (1953).

(92) Spretnak, J. W., "Kinetics of Solidification of Killed Steel Ingots", Trans. ASM, 39, 569 (1947).

(93) Spretnak, J. W., "Vertical Solidification", Iron Age, 167, 107 (1951).

(94) Weills, N. D., and Ryder, E. A., "Thermal Resistance Measurements of Joints Formed Between Stationary Metal Surfaces", Trans. ASME, 71, 259 (Apr., 1949). 


\section{CONELPan}

APPENDIX B

COMPUTATION OF ANGLE FACTORS $\left(\mathrm{F}_{\mathrm{a}}\right)$

AND EMISSION FACTORS $\left(\mathrm{F}_{\mathrm{e}}\right)$

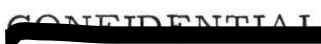

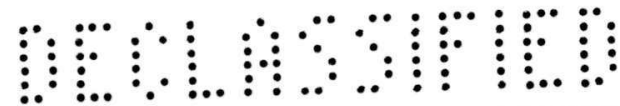




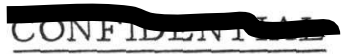

$B-1$ and $B-2$

APPENDIX B

\section{COMPUTATION OF ANGLE FACTORS $\left(\mathrm{F}_{\mathrm{a}}\right)$ \\ AND EMISSION FACTORS $\left(\mathrm{F}_{\mathrm{e}}\right)$ *}

\section{Casting Wall:}

Since the wall of the casting is enclosed by the mold, $F_{a}=1$. Also, since the casting wall is close to the mold wall

$$
F_{e}=\left(1 / E_{1}+1 / E_{2}-1\right)^{-1}
$$

where $E_{1}$ and $E_{2}$ are the emissivities of the casting and mold surfaces respectively.

\section{Outer Mold Wall:}

Since the mold is almost completely enclosed by the cooling jacket, $F_{a}=1$. The enclosed mold is not small with respect to the jacket nor is it as large with respect to the jacket as the casting is with respect to the mold; hence,

$$
E_{3}>F_{e}>\left(1 / E_{3}+1 / E_{4}-1\right)^{-1}
$$

where $\mathrm{E}_{3}$ and $\mathrm{E}_{4}$ are the emissivities of the outer mold wall and the inner surface of the cooling jacket, respectively.

\section{Top of the Casting:}

As explained in this report; ${ }^{2}$, the determination of the $F_{a}$ and $F_{e}$ factors for radiant heat loss from the top of the casting is complicated. As a first approximation, the bottom of the crucible and the top of the casting are regarded as parallel disks, connected by nonconducting but reradiating black walls. For this case, graphs are available which give $F_{a}$ as a function of the ratio of diameter of the disks to the distance between them. $F_{e}$ is given approximately by the product $E_{5} E_{6}$, where the $E^{\prime} s$ are the emissivities of the two opposite disks.

\footnotetext{
* McAdams, W. H., Heat Transmission, First Edition, McGraw-Hill Book Company, New York (1933), Table II, pp 54-55.

* See p 12 of this report.
} 


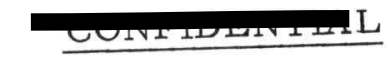

APPENDIX C

$\frac{\text { TABULA TION OF PHYSICAL CONSTANTS }}{\text { USED IN THE MATHEMATICAL MODEL }}$

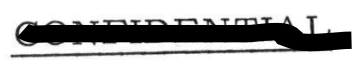




$$
\mathrm{C}-1 \text { and } \mathrm{C}-2
$$

\section{APPENDIX C}

\section{TABULATION OF PHYSICAL CONSTANTS USED IN THE MATHEMATICAL MODEL}

The physical constants used in the mathematical study are given below. Since in some cases they were obtained by extrapolation or simple assignment based on what might reasonably be expected, all sources have been purposely omitted. They have been presented because their omission would be obvious, and in the hope that comments pertaining to the choice of values will be forthcoming. The temperature range of specific interest is $1000 \mathrm{C}$ and above. The materials are as-cast reactor-grade uranium and Speer's International Type 7100 graphite.

\section{Uranium}

(1) Thermal conductivity of the solid $(a)$

$0.033+1.0087 \times 10^{-4} \mathrm{~T} \mathrm{cal} /(\mathrm{sec})(\mathrm{cm})(\mathrm{C})$

(2) Thermal conductivity of the liquid

(3) Specific heat

$0.149 \mathrm{cal} /(\mathrm{sec})(\mathrm{cm})(\mathrm{C})$

(4) Heat of fusion

(5) Density (at 1050 C)

$0.03843 \mathrm{cal} /(\mathrm{g})(\mathrm{C})$

$11.54 \mathrm{cal}$ per $\mathrm{g}$

$17.56 \mathrm{~g}$ per $\mathrm{cm}^{3}$

Graphite-Speer International Type 7100

(1) Thermal conductivity (a)

(2) Specific heat

(3) Density

$0.4-2.83 \times 10^{-4} \mathrm{~T} \mathrm{cal} /(\mathrm{sec})(\mathrm{cm})(\mathrm{C})$

$0.31 \mathrm{cal} /(\mathrm{g})(\mathrm{C})$

$1.6 \mathrm{~g}$ per $\mathrm{cm}^{3}$

(a) These are linear approximations to the thermal conductivity as a function of temperature in the range of interest.

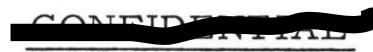

